
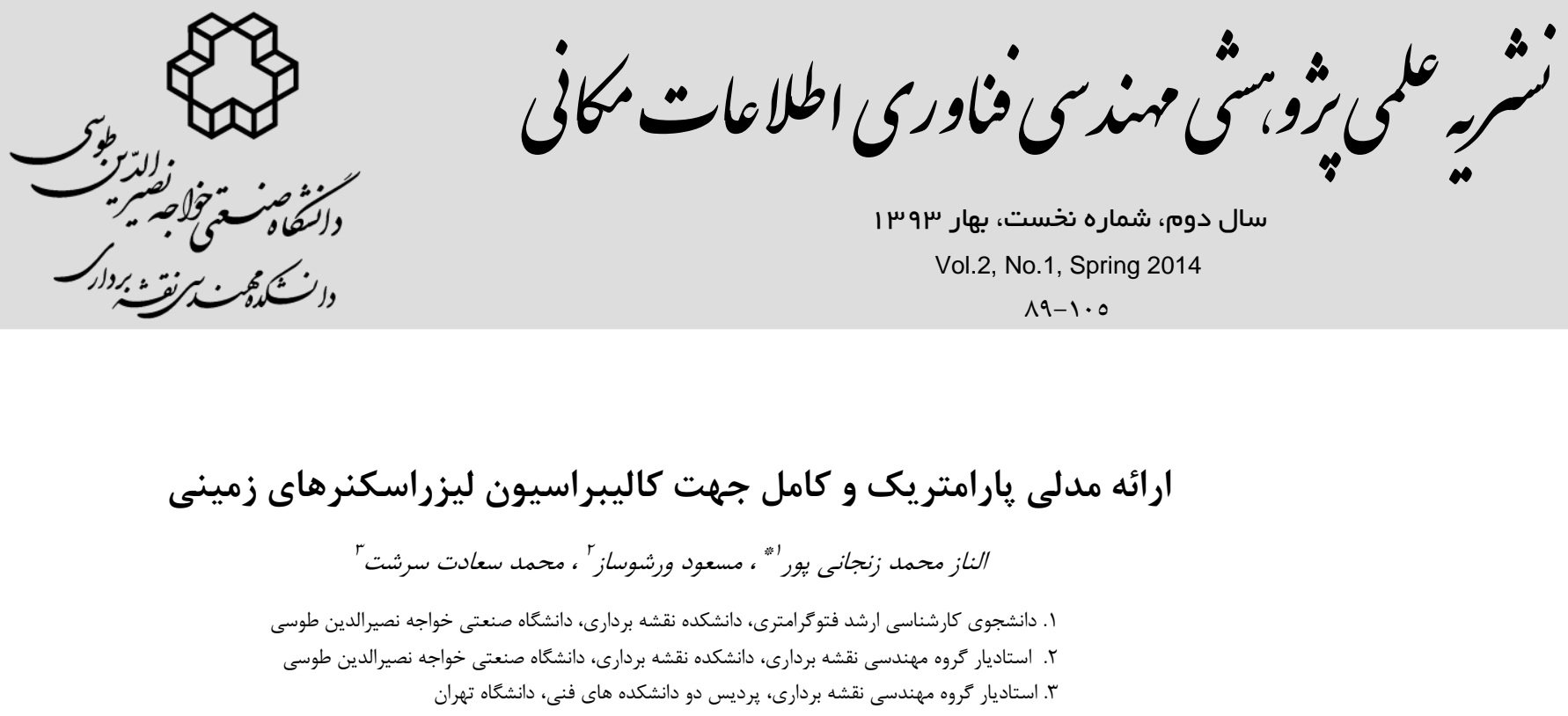

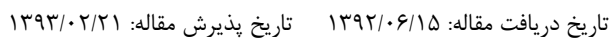

جكيده

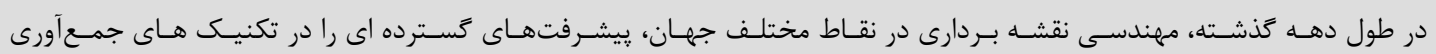
دادهاى مكانى داشته است. از بين راه هاى مختلف يِيشنهادى، يكى از اين جديدترين اين توسـعه هـا بـه صـورت اسـتفاده از تكنولـوزى ليزر اسكنر ظاهر شده است. متد ليزر اسكنر به استفاده كننده اجازه جمع آورى اتوماتيك و مستقيم داده هـاى سـه بعـدى را داده اسـت. تحقيق در خصوص عوامل تأثير كذار بر دقت و منابع آن ها، در اندازمخيرىهاى ليزر اسكنر به دليل عوامل زياد تأثيرگَذار بسـيار، سـت و يِيجيده مى باشد. بنابراين بدليل وجو خطاهاى مختلف آنجه در مورد اين ابزار لازم به نظر مىرسد كاليبراسيون آنها مسى باشـد. تـا كنـون مدل هاى مختلفى جهت بهبود كيفيت داده هاى ليزر اسكنر ارائه شده اسـت. در ايـن مقالـه بـر اسـاس سـاختار داخلـى ايـن دسـتخاه، مدلى پارامتريك جهت كاليبراسيون ابر نقاط حاصل ارائه مى شود كه اثر آن بـر كيفيـت داده هـاى حاصـل از ايجـاد يـك ميـدان آزمـون مورد ارزيابى قرار كرفته است. مقايسه اين مدل با مدل هاى ارائه شده توسط ديخر محققين نشان دهنده اين مطلب است كه بدليل اينكـهـ تنها در بردارنده پِارامترهاى فيزيكى است و بر خلاف مدلهاى ديخر يارامتر تجربى را شامل نمىشود براى انـواع مختلفى از ليزراسـكنرها

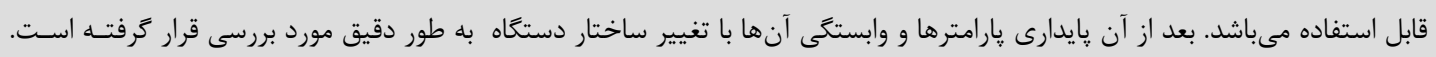
با محاسبه يارامترهاى مدل و ارزيابى وابستكىى آنها و اعمال آنها بر دادههاى ابر نقاط مشاهده مىشود كه اين مـدل بـا پايـدارى نسـبى. يارامترها، مىتواند دقت دادهاى ليزر اسكنر زمينى را بهبود بخشد.

* نويسنده مكاتبه كننده: الناز محمد زنجانى يور: تهران،خيابان وليعصر،روبروى ساختمان اسكان،دانشكده نقشهبردارى دانشكاه خواجه نصيرالدين طوسى، آزمايشكاه فتوكرامترى Email: e.zanjanipour@gmail.com 


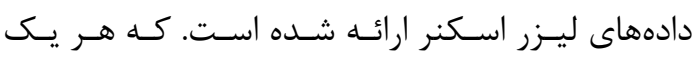

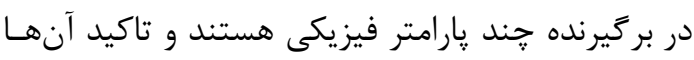
در ادامه در خصوص يارامترهاى تجربى است كه بعـد از

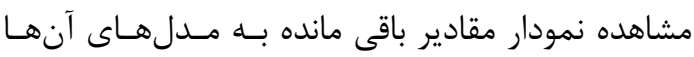

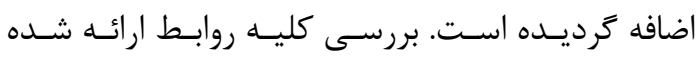

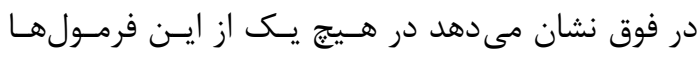
ساختار داخلى دستخاه به شكل كامل مدل نشده استـ،

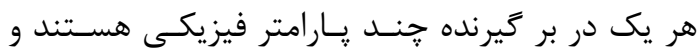

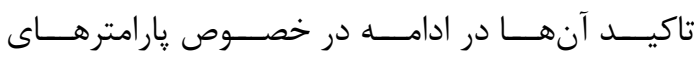

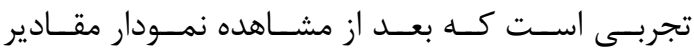

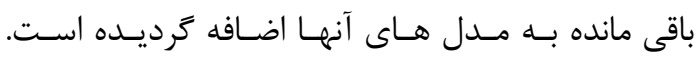

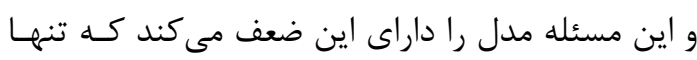

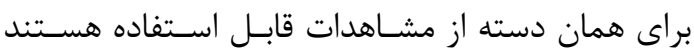
جون در جـاى ديكـرى ممكـن اسـت ايسن :ارامترهـاى

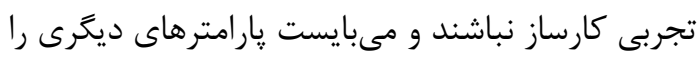
جايكزين آنها نمود. به همــين دليـل در ادامـهـ بعـد از بـاز مرورى بر مدلهـاى محققـين ديخـر، مـدلى جديـد در

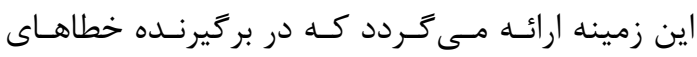

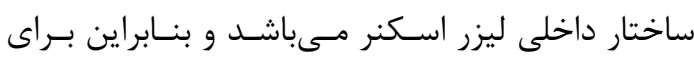

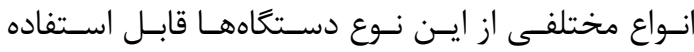

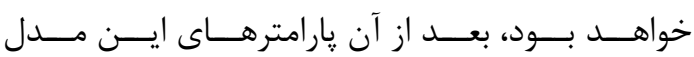

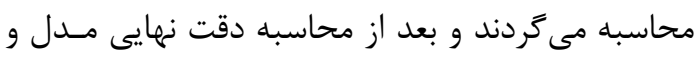

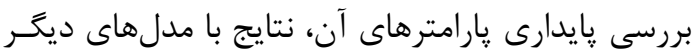

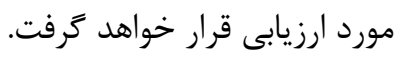

\section{r- ارائه مدل پييشنهادى}

مشكل مدل كردن سنجنده شايد مهــمتـرين بخـش در

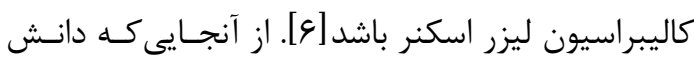
درخصوص عملكرد داخلى ليزراسكنرهاى زمينى بلهدليل خصوصيات انحصارى در طراحسى كـهـ سـازنده ترجيحـاً آنها را بيان نمى كند، بسيار محدود مى بـاشد و يـا اصـلاً

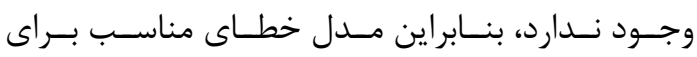
ليزر اسكنر زمينى با تمركز بر فرضيات ايجاد مىشود.

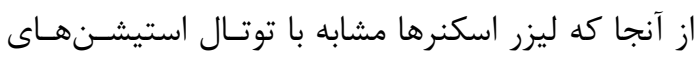
بدون رفلكتور عمل مى كنند اغلب محققين مدل خطاى

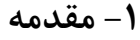
فناورى ليزر اسكنر به دليل قابليتهايى كه در مقايسـه با ساير روشهاى زئودتيك دارد، روز به روز بيشتر مورد علاقه كاربران قرار مى گيرد. در عين حال به دليل وجود عوامل مختلف، نتايج حاصـل از انـدازه كيـرى دسـتـاه، تحت تاثير اثرات گوناگون، خطا دار خواهد بود. آنجه در

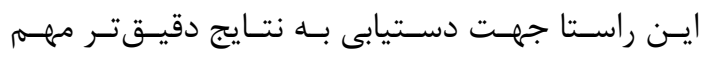
به نظر مىرسـد، كاليبراسـيون مـىباشـد كـهـ در واقـع مجموعهاى از عملياتها است كه تحت شرايطى خـاص

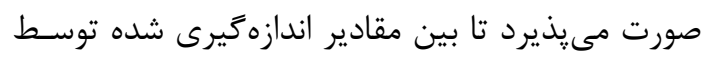

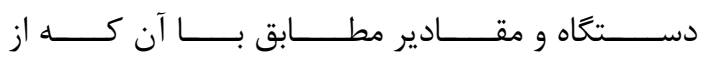

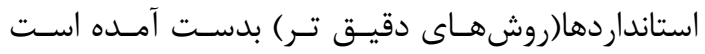
ارتباط بر قرار نمايد. [ه]]. روش كاليبراسيون معمـول بـراى انـواع وسـايل و ابـزار فتو گر امتريك و زئودتيك وجود دارد. اما اين موضـوع در درو

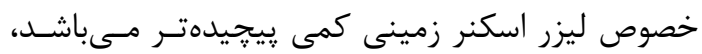

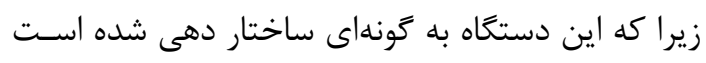

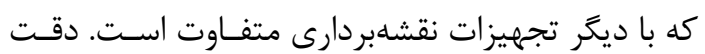

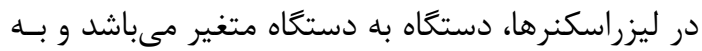

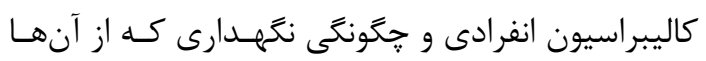

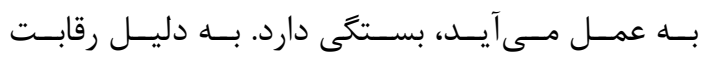
بين سازندههاى مختلف، طراحى ليزر اسكنر به صـورت

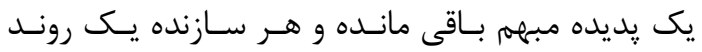

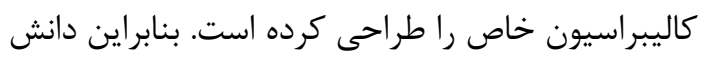
در مورد كاليبراسيون اين دستخاهها بسيار محدود است.

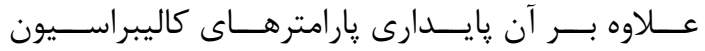

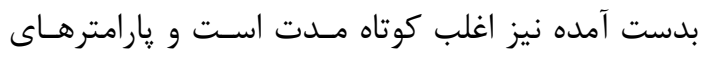
محاسبه شده در يك يروزه، فقط براى همان دسـتخاه و همان مشـاهدات مناسـب مـىباشـــد زيـرا بـراى تمـام

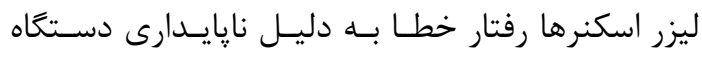

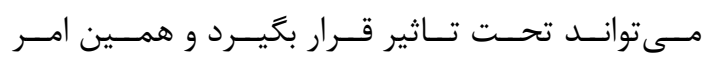
موجب مىشود كه يارامترهاى محاسبه شده نيز نايايدار

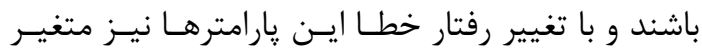
خواهند بود. تـا كنــون مـدل هــاى مختلفـى جهـت بهبــود كيفيـت 
تجربه نشان داده اسـت كـهـ ايـن يارامترهـا مهـهمترين

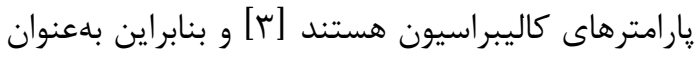
مبناى مــل كاليبراسـيون در نظـر كرفتـه مسىشـوند.

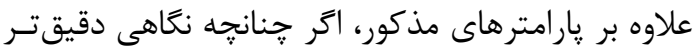

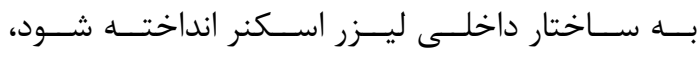

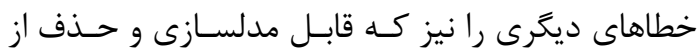

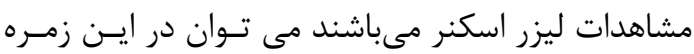

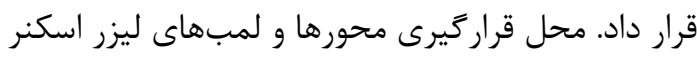
در شكل زير( ) قابل مشاهده است.
توتال استيشن را بهعنوان مدل پايه بـراى كاليبراسـيون

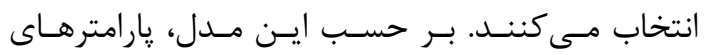
كاليبراسيون به صورت زير بيان مىكردند:

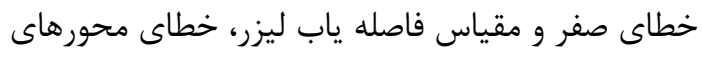
افقى و كليماسيون، خطاى شاخص لمب قائم في لماصل مجموع جهار يارامتر فوق به صورت زير بـهـ مشـاهدات

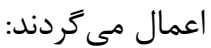

$$
\begin{aligned}
& \Delta \rho=a_{0}+a_{1} . \rho \\
& \Delta \theta=\frac{b_{1}}{\cos \varphi_{j}^{(i)}}+b_{2} \tan \varphi_{j}^{(i)} \\
& \text { رابطه (1) } \\
& \text { رابطه (T) } \\
& \text { رابطه (Г) }
\end{aligned}
$$

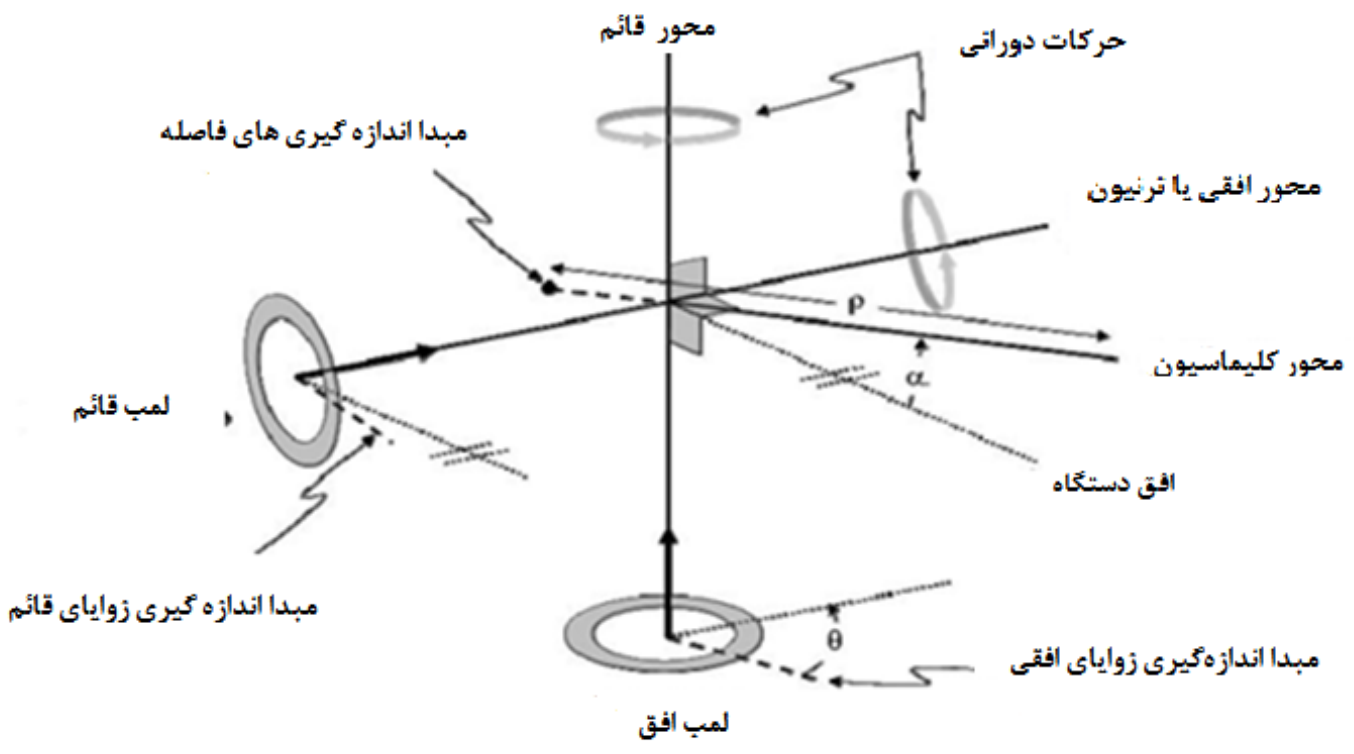

$$
\text { شكل ا: محل قرار تيرى محور ها و لمب هاى ليزر اسكنر }
$$

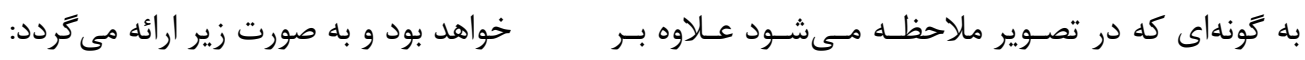
$\Delta \rho=a_{0}+a_{1} \cdot \rho+a_{2} \cdot \sin \varphi$ خطاهاى فوق الذكر مى توان خطاهاى ديخرى را برشمرد

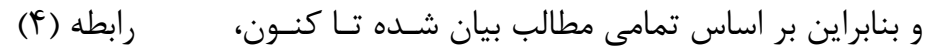

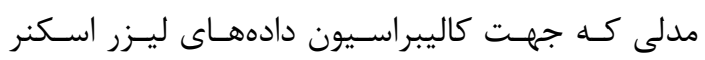

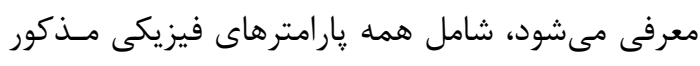

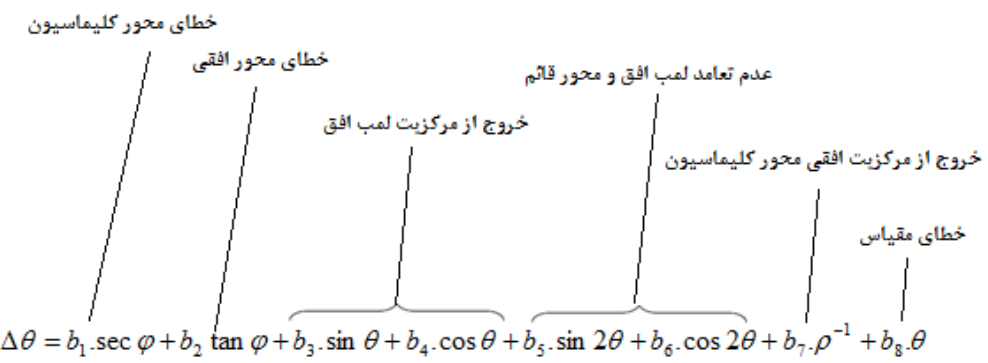




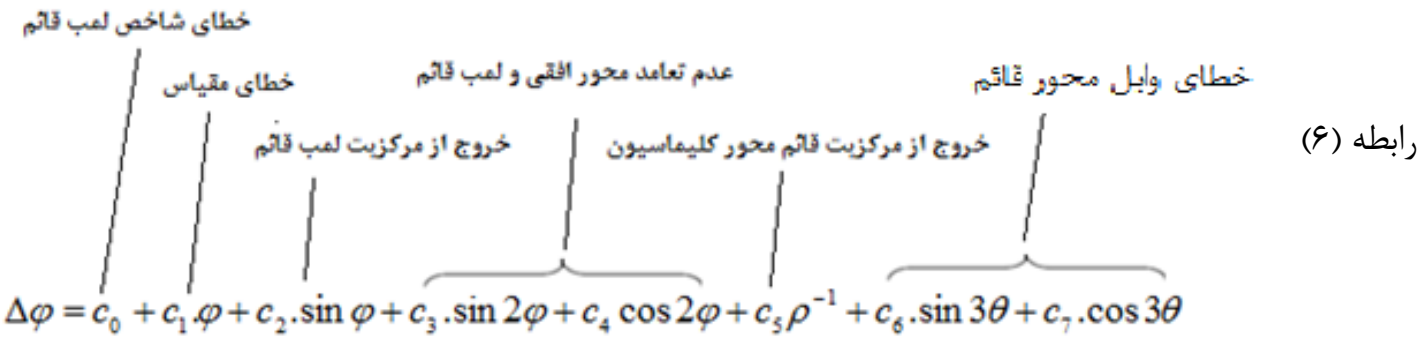

تا به اين ترتيـب و از طريـق ايـن مقايسـه تـاثير مــدل بيشنهادى بر دقت مختصات نقـاط مـورد ارزيسابى قـرار بخيرد. لازم به ذكر است كاليبراسيون صورت كرفتسه در

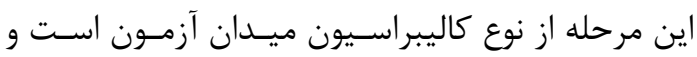

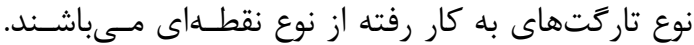

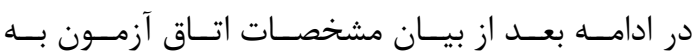
تشريح مراحل اجرايى يرداخته مىشود.

ץ- مشخصات اتاق آزمون و تاركـت هــاى مـورد

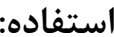

اتاق آزمون، آزمايشكاه فتوكرامترى در دانشگاه تهران به

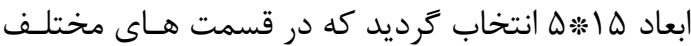

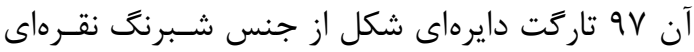

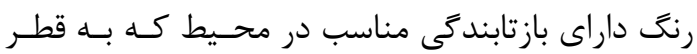

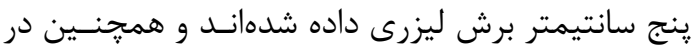
مركز آنها سوراخى توسط ليزر ايجاد شده بود بهصورت

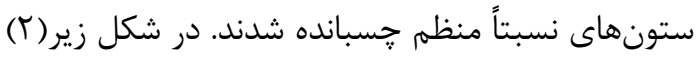
تصوير ينوراماى اتاق آزمون نشان داده شده است.
به اين ترتيب سه معادله فوق با 19 يارامتر فيزيكى(كه

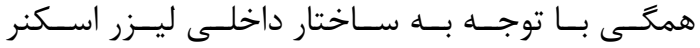
در نظر كرفته شدهاند)جهت كاليبراسيون و بهبود دقـت

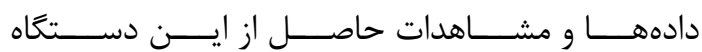
معرفى ترديدند. جهت محاسبه يارامترها لازم است مختصات نقاط علاوه

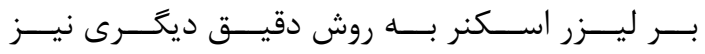
اندازه كيرى شوند و با برقرارى روابـط ترانسفورماسـيون

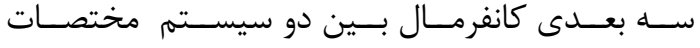

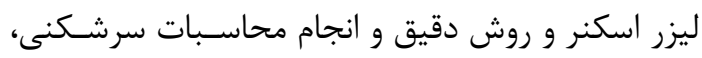
مقادير آنها بدست آينـد. بــراى ارزيــابى دقيـق ميـزان

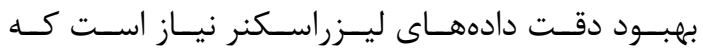
دقت مشاهدات ليزر اسكنر قبـل و بعـد از اعمـال مـــل ليـل

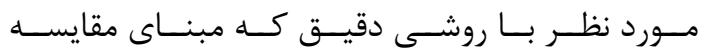
قـرار مسى گيــرد محاسـبه و بــا هـم مقايسـهـ خــردد. بامنظور ارزيابى مدل بدست آمده، مختصات تاركـتهــا

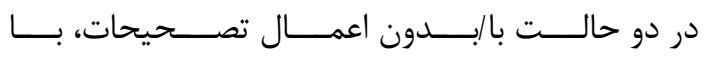
مختصات حاصل از روش مرجع كه در اين تحقيق روش فتو گرامترى در نظر گرفته شده است مقايسه گرديدنـد.

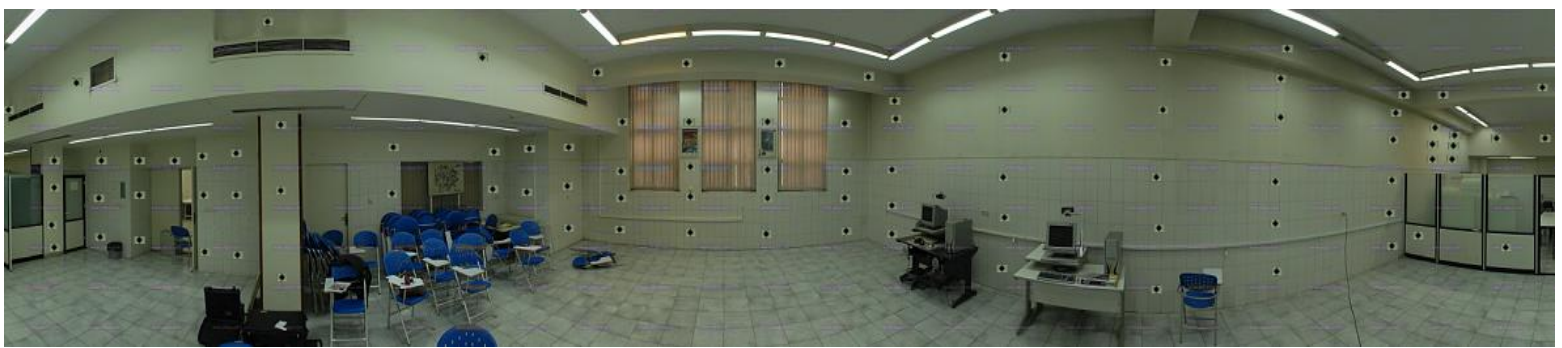

شكل ז: تصوير پِنوراماى اتاق آزمون

ץ-1- مشاهدات صورت ترفته توسط ليزر اسكنر

در هـــر يـروزه ليــزر اسـكنر در اســقرارهاى مختلــف
F- تشريح مراحل صورت گرفته

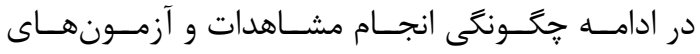
صورت كرفته به تفصيل بيان مى گرددد. 


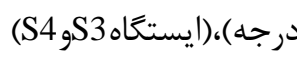

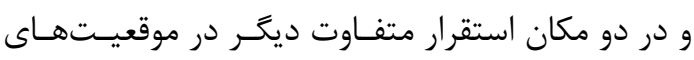
شماره دو و سه، (ايستخاه S6و S7) مستقر گرديــد (در كـل هفـت اسـتقرار) و و و تاركـت

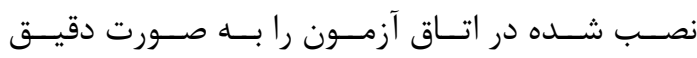
برداشت نمود. همان گونه كه بيان شد، از دلايل اصلى اين تنوع و تغيير

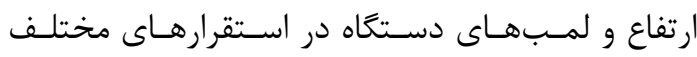

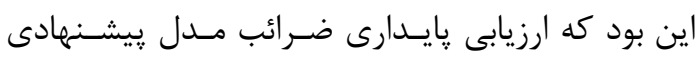

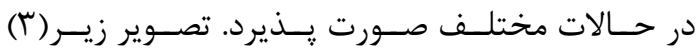

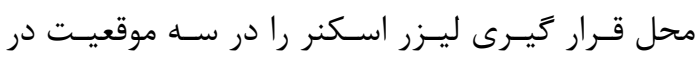
اتاق آزمون در تصوير ینوراما نشان مى دهدي.
مشاهدات را براداشـت مـىنمايسد. محـل قرارگيـرى در

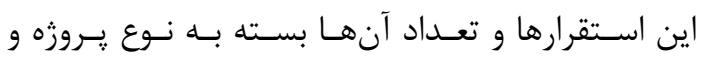

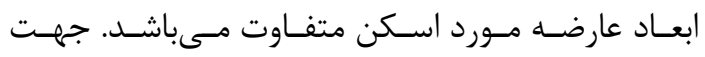
برداشت مختصات تارگت ها، ليزر اسكنر در سه ايسـتخاه

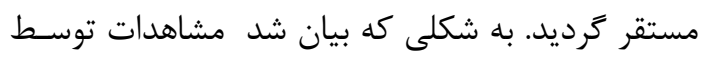
ليزر اسكنر ريكل LMSz420i انجام پِيرفت. با استقرار دستخاه در سه موقعيت، برداشت بر اساس مراحـل زيــر

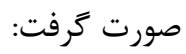
در موقعيت شماره يك كه تقريباً وسط اتاق قرار داشت: الف- در دو ارتفاع متفاوت، (ايستخاه S1S1 S5)

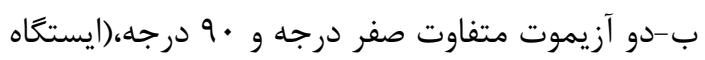
( S2,S1 ج-دو تغييـر در لمسب قـائم در شـيب( • + + درجـه، •r-

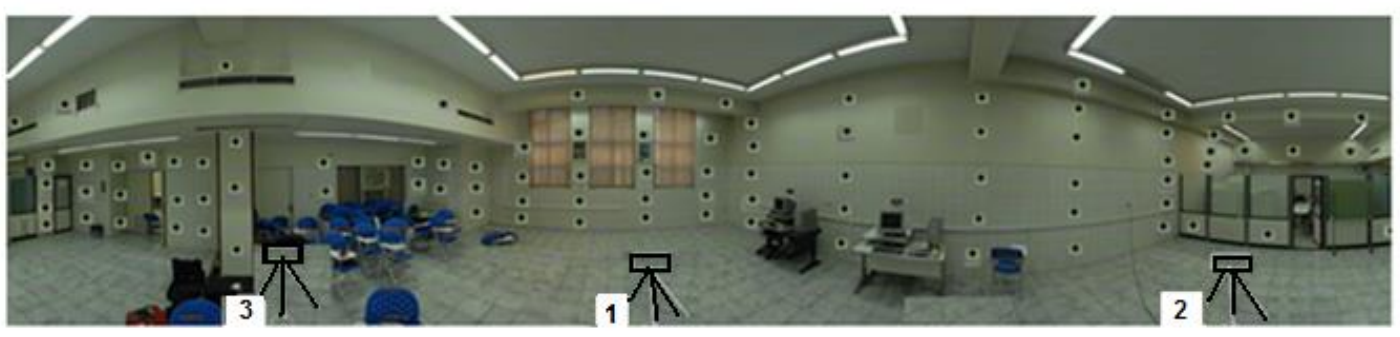

شكل ז:محل قرار گَيرى ليزر اسكنر در سه ايستگًاه در تصوير ينوراما

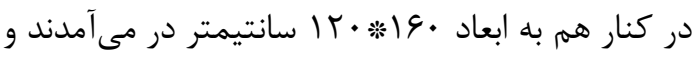

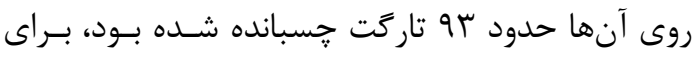

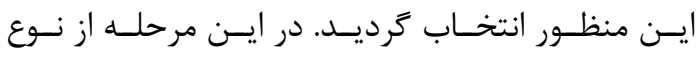

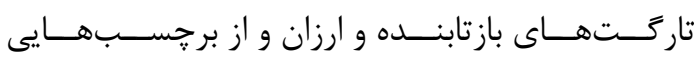

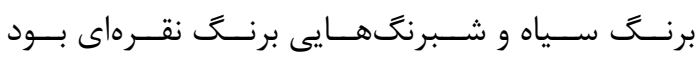

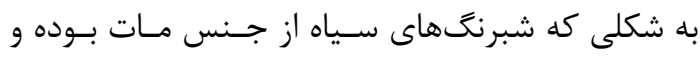
شبرنگ هاى نقره اى داراى بازتابندگى در محسـيط نيمــهـ

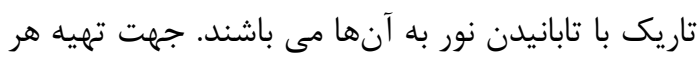

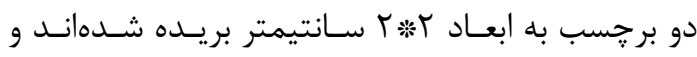

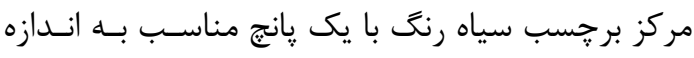

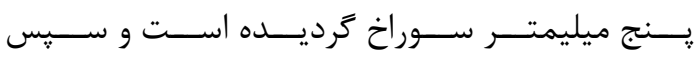

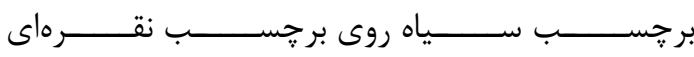
קسبانيده شده است. يانج مورد استفاده داراى لبههـاى

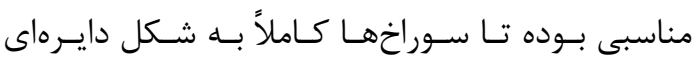

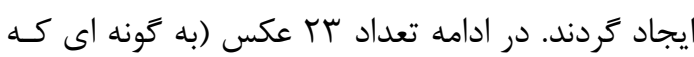

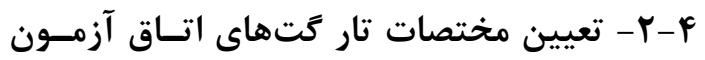
بهصورت دقيق

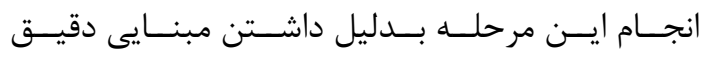
جهت ارزيابى دقت مشـاهدات ليـزر اسـكنر مـورد نيـاز

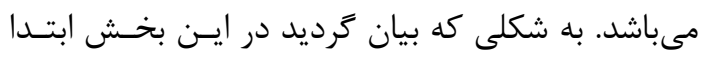

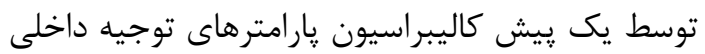

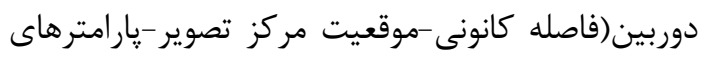

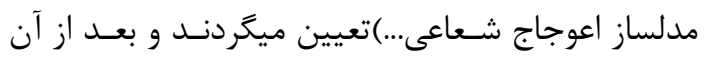
با انجام عكسبردارىها از اتاق آزمون مختصات تاركتها در نرمافزار استر اليس تعيين مى دركردند.

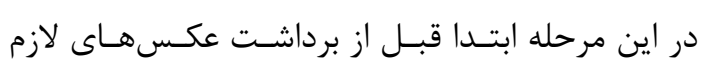

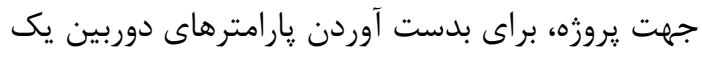

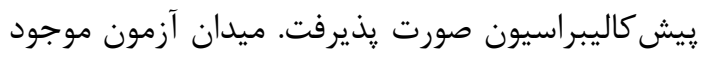

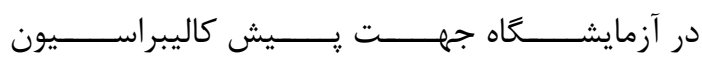

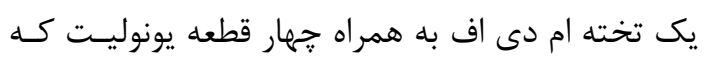




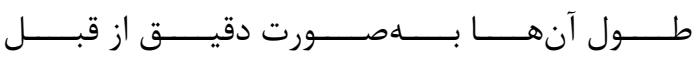
اندازهزيرى شده است. در شكل(أ) زير ميـدان آزمــون فئن

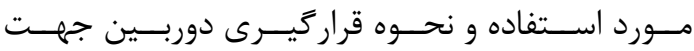
عكسبردارى نشان داده شده اسـت. خطـوط موجــود در ميدان آزمون نمايانگر اسكيل بارها مىباشند.

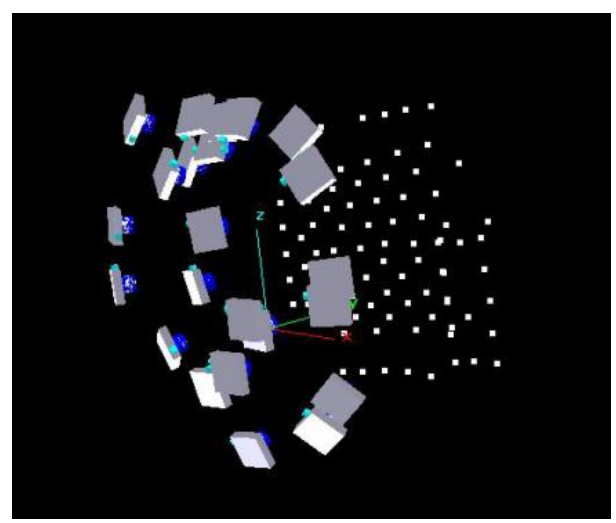

در برخى از استقرارها نيز دوربين يك عكس مسى

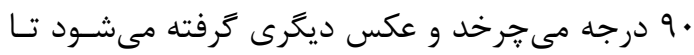

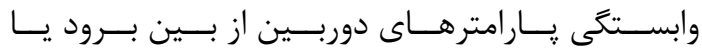
كاهش بيابد.) گرفته شد. سيس عكس هـا در در نرم افزار وارد مىشوند و يردازش مى گردند. در اين فرآيند شـش

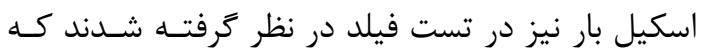

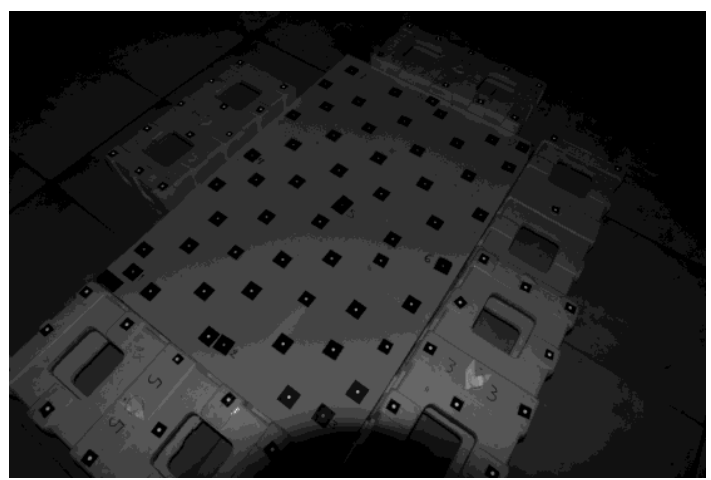

شكل foscale bar تصا.

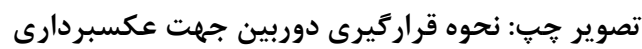

در اين قسمت مقادير يارامترهاى دوربين محاسبه شـده در مرحله يیش كاليبراسيون در نرمافزار وارد و در طول

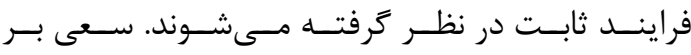

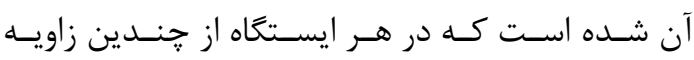

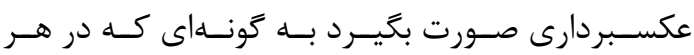

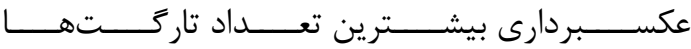

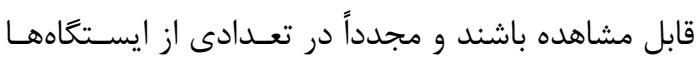

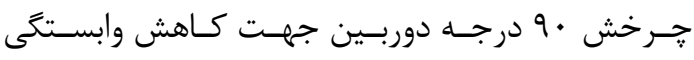
يارامترهاى آن صورت يذيرفته است.

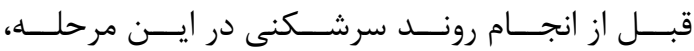
جهت محاسبه مختصات نقاط در مقياس حقيقىى، نيـاز به داشتن اندازههــاى دقيـق تعـدادى اسـكيل بـار بـود.

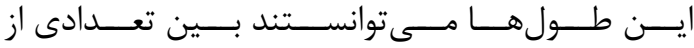

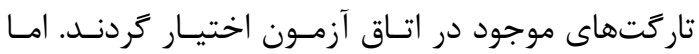

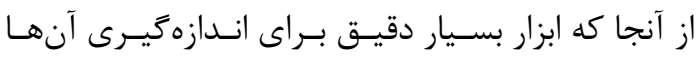

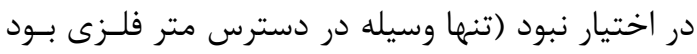
كه در جنين اندازه گيرىهاى دقيقى نمى تواند بهعنوان

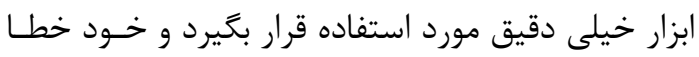

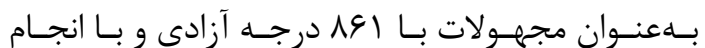
سرشكنى نرمافزار rmse نهايى را براى طولهاى مبنا به

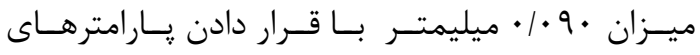

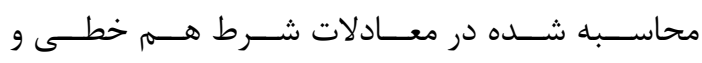
محاسبه مقادير باقى مانده از طريق رابطه زير ارائه داد.

$$
\begin{array}{cr}
d=\sqrt{\left(x^{\dagger}+y^{\dagger}+z^{\dagger}\right)} & \text { (V) رابطه }
\end{array}
$$

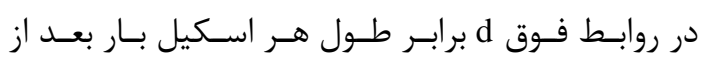
جايخَذارى يارامترهــاى محاسـبه شـده در معــادلات شرط همخطى، X و و Y X مختصات جديد محاسبه شـده براى هر تارگت و n مختصات برابر تعداد اسكيل بـار هــا مىباشد. بعد از محاسبه يـارامتر هـاى توجيـهـ داخلى دوربـين جهت محاسبه مختصات دقيق تار زتهاى اتاق آزمـون

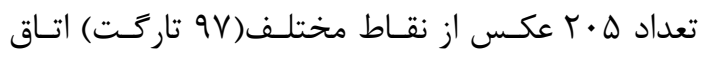
توسط دوربين رقومى گرفته مىشود. ســـ عكسـسهـا

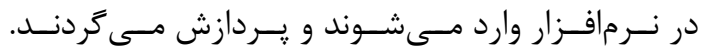




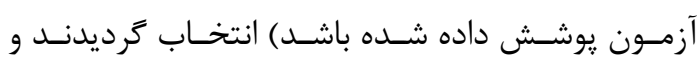

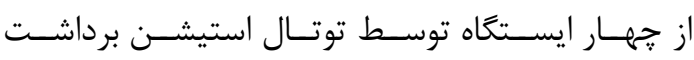

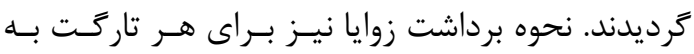

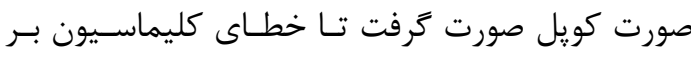
طرف شود و اطلاعات برداشتى دقيق باشند. بنابر اين در

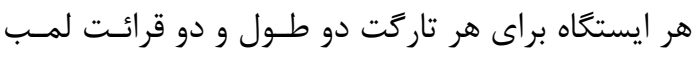

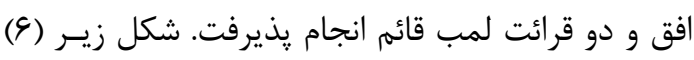

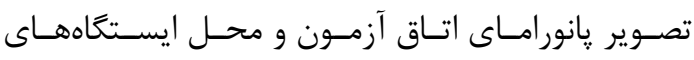

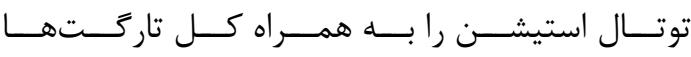

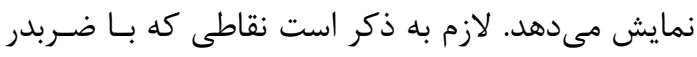

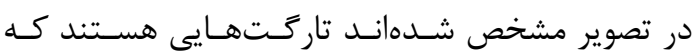
توسط توتال استيشن قرائت شدهاند.
دار مىباشد و جاكَونكى قراركيرى آن نيز بهعنوان مثنال

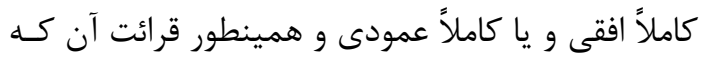

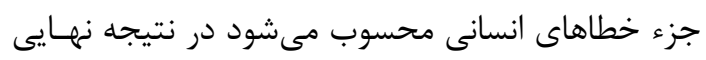

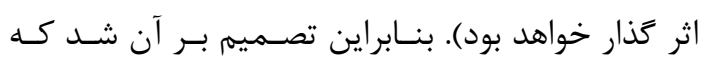

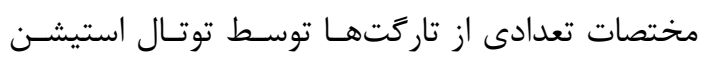

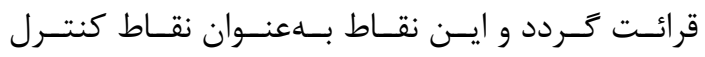

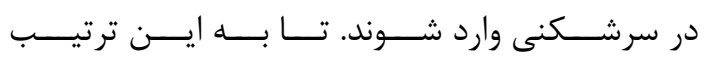

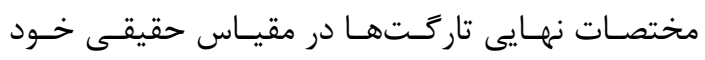

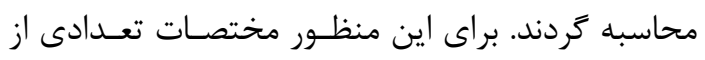

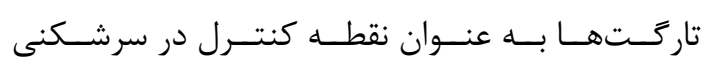

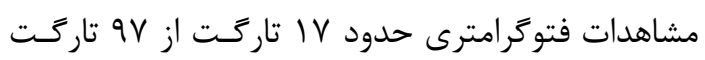

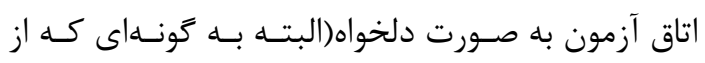
هر ديوار جند تاركَت در نظر كرفته شدند كه كـل اتـاق

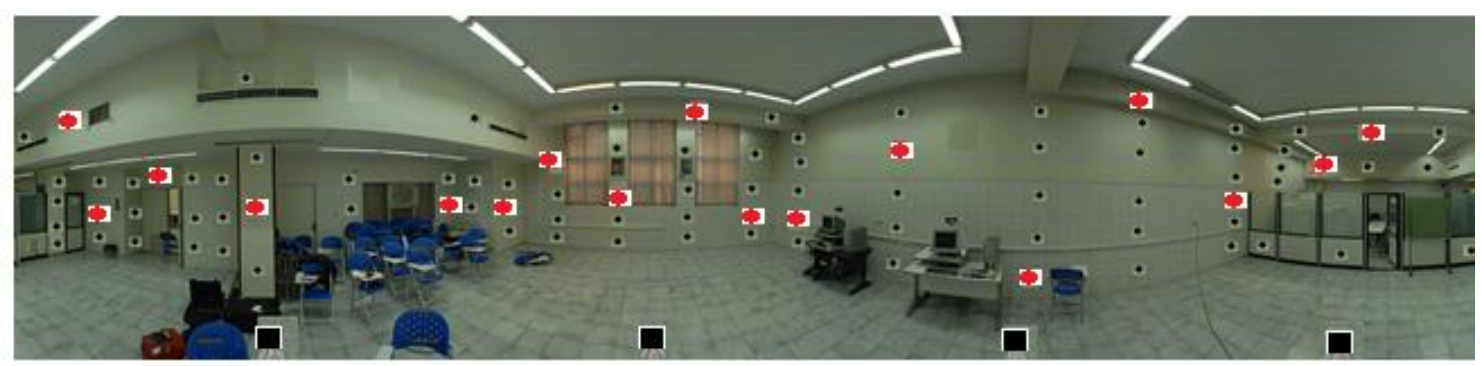

شكل \&: تصوير اتاق آزمون و محل ايستَاه هاى توتال استيشن.نقاط ضربدر:تاركت هايى كه با توتال قرائت شده اند.

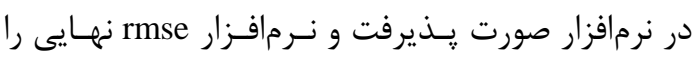

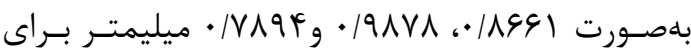
مقادير Z،y،x إئه داد.

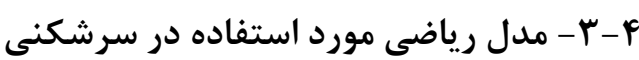
معادله مشاهده ترانسفورماسـيون كانفرمـال سـهبعـدى

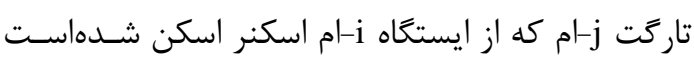
مى تواند به شكل زير نوشته شود:

$$
f^{i}{ }_{j}\left(L_{j}^{i}, \hat{X}^{i}{ }_{j}\right)=X_{\text {photo } j}^{i}-\left[R\left(\omega^{i}, \phi^{i}, \kappa^{i}\right) \cdot x_{\text {scan } j}+T^{i}\right] \quad ; \quad i=1,2, \ldots p \quad j=1,2, \ldots m \text { (9) }
$$

جهت ترانسفورماسـيون بـين مختصـات ليـزر اسـكنر و فتو ${ }^{i}{ }_{\text {photo j }}$.
بعد از بستن شبكه نقشهبـردارى و محاسـبه مختصـات

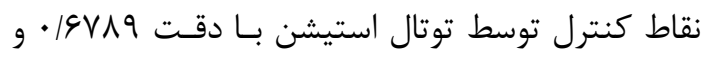
آ

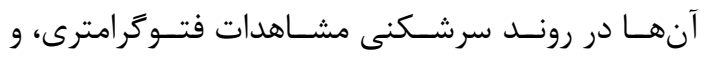
در نظر گرفتن تعداد معادلات(دو معادله براى هر نقطـهـ

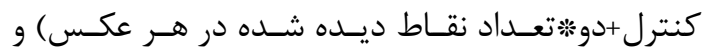

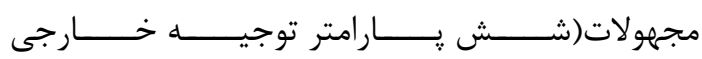
هر عكس+(تعداد تاركت ها+تعـداد نقـاط كنترل)ش*شـهـ)

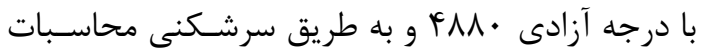
جائى كه در آن p تعداد استقرارهاى دستخاه و m تعـداد تارگتهاى اسكن شده در هر استقرار مىباشد. در رابطه فوق T و R به ترتيب شامل يارامترهاى انتقـال و دوران 
مىباشد كه در صورت اعمـال رابطــهـ تصـحيح شـده آن

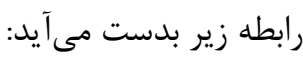

بـردار مختصـات تاركـت ز-ام را در سيسـتم مختصـات فتوكرامترى و j ام در استقرار i ام در سيستم مختصـات ليـزر اسكنر

$x_{s c a n j}^{(i)}=\left[\begin{array}{c}x_{j}^{(i)} \\ y_{j}^{(i)} \\ z_{j}^{(i)}\end{array}\right]=\left[\begin{array}{l}\left(r_{j}^{(i)}-\Delta r\right) \cos \left(\phi_{j}^{(i)}-\Delta \phi\right) \cos \left(\theta_{j}^{(i)}-\Delta \theta\right) \\ \left(r_{j}^{(i)}-\Delta r\right) \sin \left(\phi_{j}^{(i)}-\Delta \phi\right) \cos \left(\theta_{j}^{(i)}-\Delta \theta\right) \\ \left(r_{j}^{(i)}-\Delta r\right) \sin \left(\theta_{j}^{(i)}-\Delta \theta\right)\end{array}\right], \quad i=1,2, \ldots, p ; j=1,2, \ldots m . \quad(1 \cdot) \quad$ رابط

آنجا كه ممكن است بين קارامترهـاى مــل بيشـــهـادى

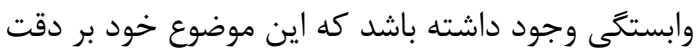

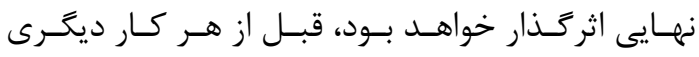

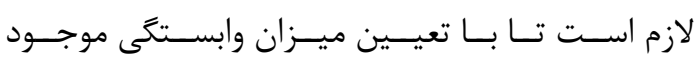
بين مجهولات بدست آمده و حذف يارامترهـاى وابسـته

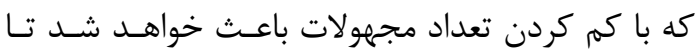

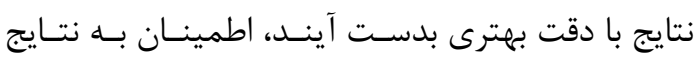

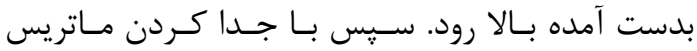

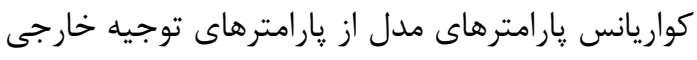

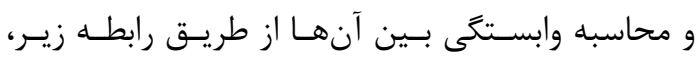

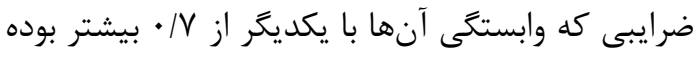

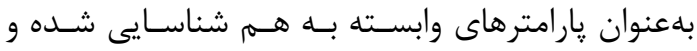

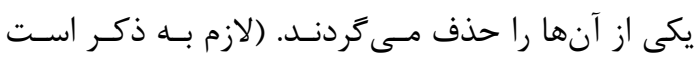

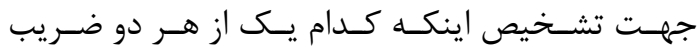

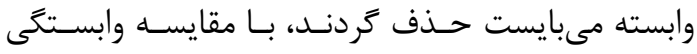

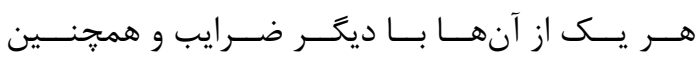

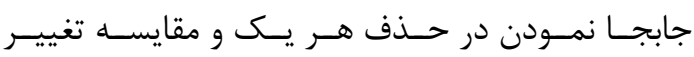

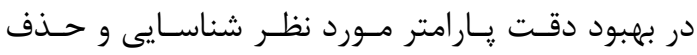
كرديد). در ايـن ارزيـابى سـه هـار امتر

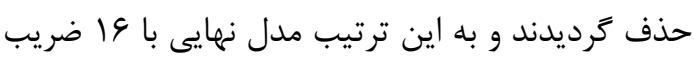

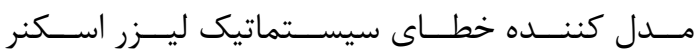

$$
\text { به صورت زير در خواهد آمد: }
$$

$\Delta \rho=a_{0}+a_{1} \cdot \rho+a_{2} \cdot \sin \varphi$

رابطه (1)
در رابطه بالا r و و و جهت افقى مى باشند كه همان مشاهدات خامى هستند

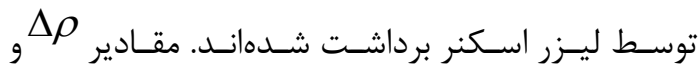

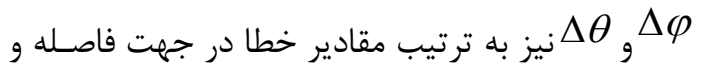

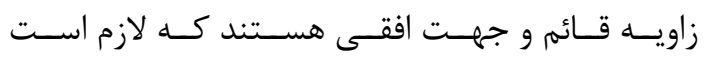

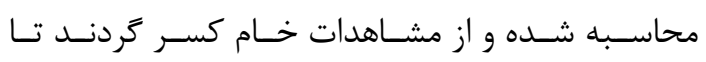
مقادير بهبود يافته مشاهدات بدست آيند. و اين مقـادير

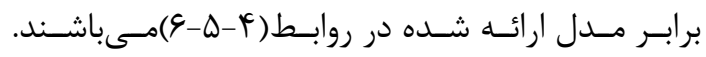

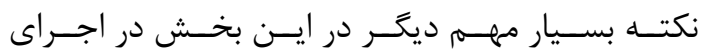

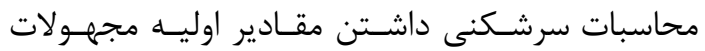
است. براى اين منظور و جهت تعيين پارامترهاى اوليـهـ

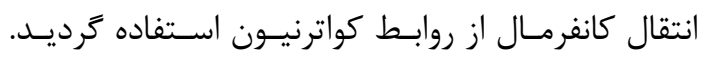

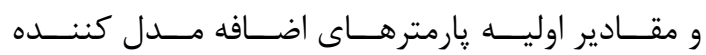

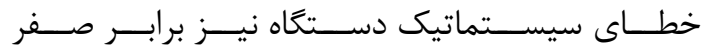

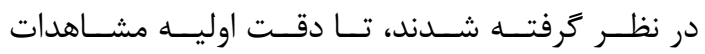

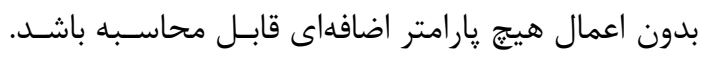

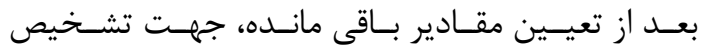

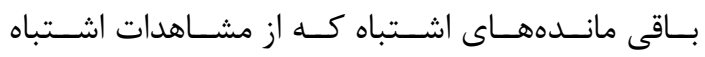

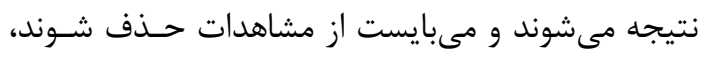

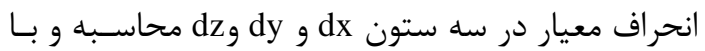

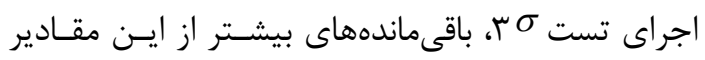
شناسايى و مشاهدات مربوطه آنها حذف شوند.

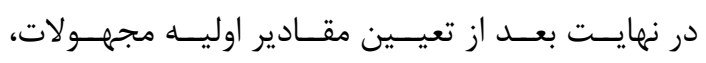

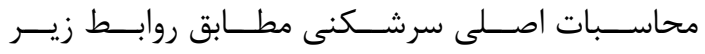

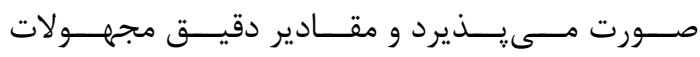

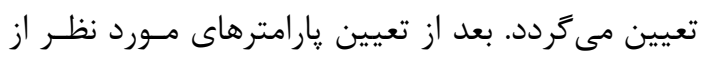


در جدول زير ميزان rmse براى فاصله و جهـت افقى و

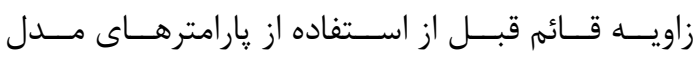

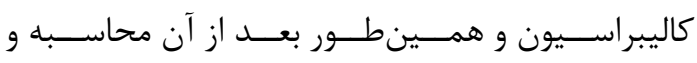

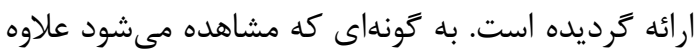
بر مطالب فوق درصد بهبود دقت نتايج بعد از استفاده از

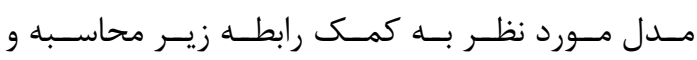
در جدول( ) نمايش داده شده است.

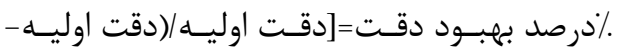

$$
\text { دقت ثانويه)] }
$$

F-F - P - Pرسى ميزان بهبود دقت يارامترهاى مدل ارائه شده

به كونهاى كه بيان شد بعـد از انجـام رونـد سرشـكنى،

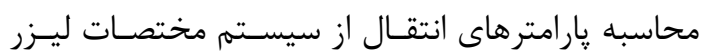

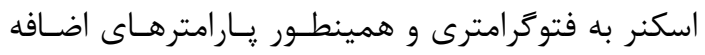

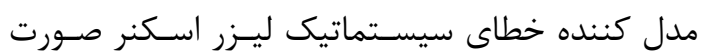

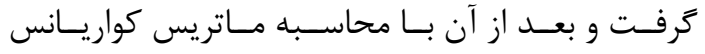

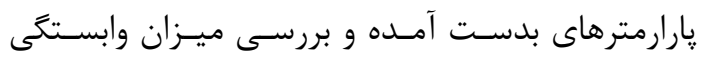

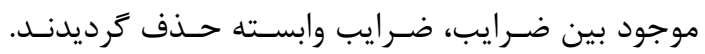

جدول ا: ميزان rmse داده هاى ليزر اسكنر بعد از حذف يارامتر هاى وابسته مدل پِيشنهادى و درصد بهببود

\begin{tabular}{|c|c|c|c|}
\hline Rmse & كاليبراسيون اوليه بدون إمترهاى & 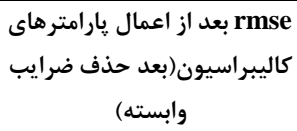 & درصد بهبود دقت ٪ \\
\hline rmse $\rho(\mathrm{mm})$ & 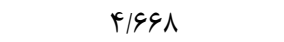 & T/FFGF & $\%$ \\
\hline rmse $\theta(\mathrm{rad})$ & $.1 \cdot 9$ & $\cdot 1 \cdots \Delta$ & $\% 1$ \\
\hline rmse $\varphi(\mathrm{rad})$ & (... & •...r & $\%$. \\
\hline
\end{tabular}

خطاى كواترنيون جهت محاسبه يارامترهاى اوليه انتقال

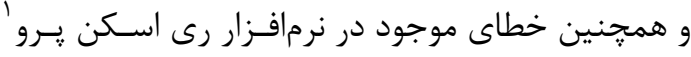

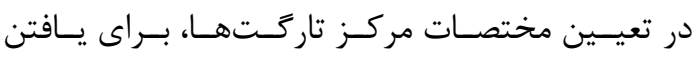

خطاى سيستماتيك اسكنر جشم پوشى خواهد شد. بعد از اعمال پيارامترهاى فيزيكى دستخاهى بـهـ نتـايج و

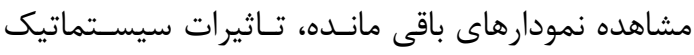

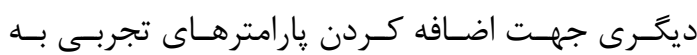

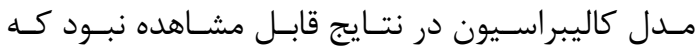

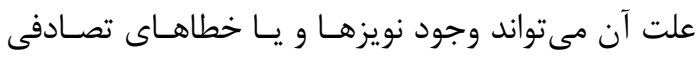
ديخر باشــد. تـا ايـن مرحلـه يارامترهـاى كاليبراسـيون

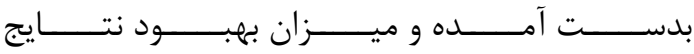

1 Ri scan pro

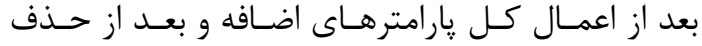

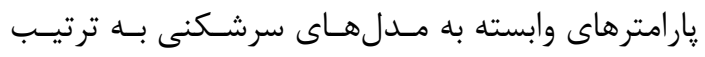

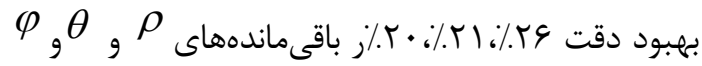

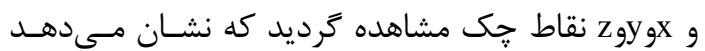

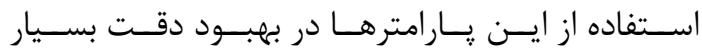

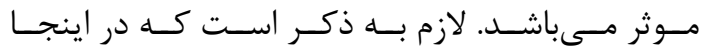
اختلاف مختصات تبديل يافته فتوكرامترى با مشاهدات ليزر اسكنر تنها به منزله خطاى سيستماتيك ليزراسكنر

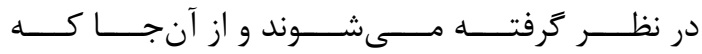

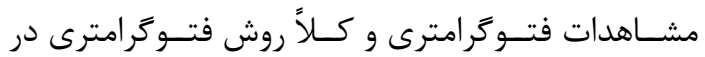
مقايسه با مشاهدات ليزراسـكنر، روش دقيـق محسـوب

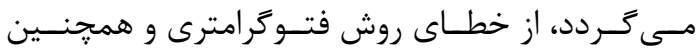


متفاوت(ايستخاههاى شمارS10، S2).

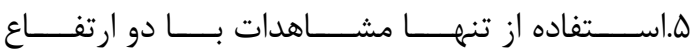

مختلف(ايستخاههاى شمارهS1، S5).

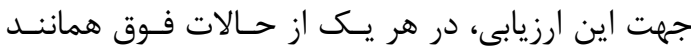

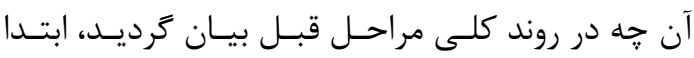

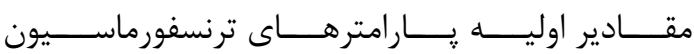

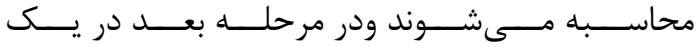

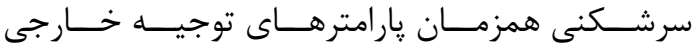

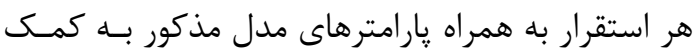

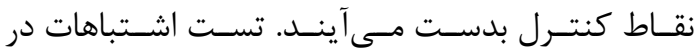

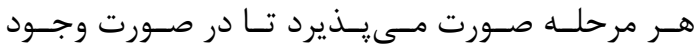

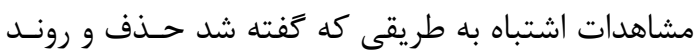
مجدد تكرار گردد. نهايتاً بعد از انجام سرشكنى در ادامه وابستخى بين يارامترهاى بدست آمده بررسى مىشود و

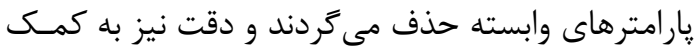

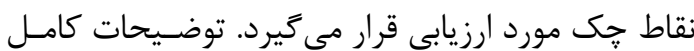
در اين خصـوص در بخـشهــاى قبـل بــه طـور مفصـل بيان شده است.

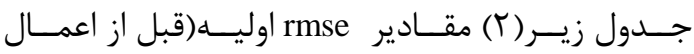

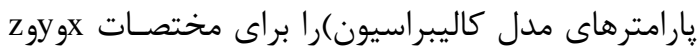
و همينطور xyz براى هر يك از حالات مختلف اسـتقرار بر حسب ميليمتر ارائه مى ندهد.

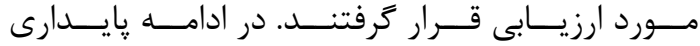
يارامترهاى بدست آمده مورد بررسى قرار خواهد گرفت.

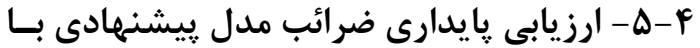
تغيير وضعيت ساختار ليزراسكنر در ايسـن بخــش هــدف ايـن اسـت كــه تعيـين شـود

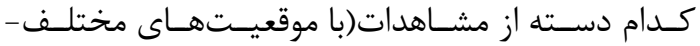
تغييـر لمــب قـائم-تغييـر لمــب افـق -تغييـر ارتفــاع)

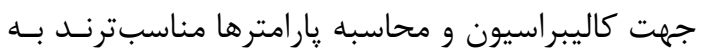
عبارت ديخر مدل ييشـــهادى در اسـتقرارهاى مختلـف تِ مورد ارزيابى قرار مى گيرد تا بررسى شود كه در صـورت

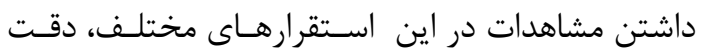
جه تغييـرى مـى كنـد و در كـدام حالـت دقت بيشـتر خواهد بود. براى اين منظور كل مشاهدات ليـزر اسـكنر به ينج حالت تقسيم مىشوند:

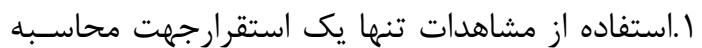

يارامترهاى مدل و بررسى دقت.(ايستخاه شماره S1).

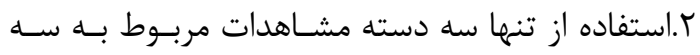

موقعيت مختلف.(ايستخاههاى شماره S1، S6، S7). ץ.استفاده از تنها سه دسته مشاهدات با صفر لمب قـائم متفاوت: •r+ درجه، درجه •، •r · درجه (ايسـتخاههـاى

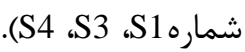

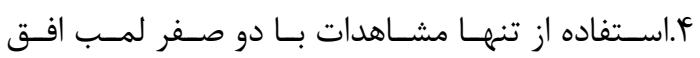

جدول r: مقادير اوليه(قبل از اعمال يارامترهاى مدل كاليبراسيون) براى مختصات zوgy و همينطور xyz براى هر يك از حالات مختلف استقرار

\begin{tabular}{|c|c|c|c|c|}
\hline نحوه استقرار & rmse & rmse اوليه & اوليه rmse $_{\mathbf{z}}$ & اوليه \\
\hline يك استقرار (A) & r/QqqV & r/घ991 & र/T৭८। & $\Delta / \varepsilon \wedge \Delta F$ \\
\hline سه موقعيت(B) & $r / \Delta 9 \wedge V$ & T/TFTH & र//V११ & D/TIYF \\
\hline سه زاويه قائم(C) & r/grto & T/RATA & r/\&QAT & $\Delta / F \wedge \varphi$. \\
\hline دو زاويه افقى(D) & r/VVrT & $r / v \cdot \Delta l$ & r/rars & $r / \lambda \cdot F r$ \\
\hline دو ارتفاع(E) & T/NTrL & r/MGG & $r / T \Delta I T$ & D/DFqV \\
\hline همه حالات(F) & r/ब८११ & r/RTV. & r/A^Vq & $\Delta / r 99 \Lambda$ \\
\hline
\end{tabular}

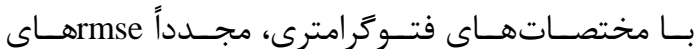

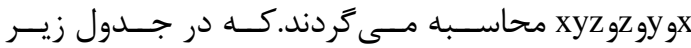

بعـد از محاسـبه مقــادير يـارامترهــاى كاليبراسـيون و همينطور اعمال آنها به مشاهدات و محاسـبه اخـتلاف مهاس 
حذف مى گردند و مجدداً rmse ها محاسبه مسى كردنـد. مقادير آنها براى حالات مختلف آمده است. بعـد از آن

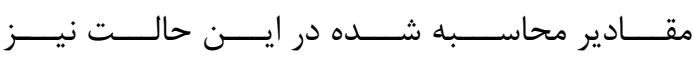

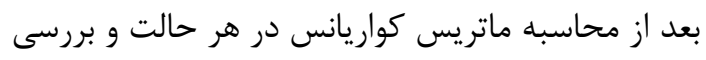
در جدول زير(ب)نشان داده شده است.

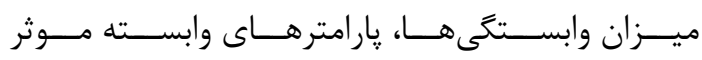

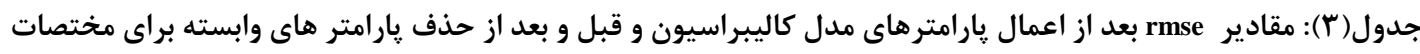

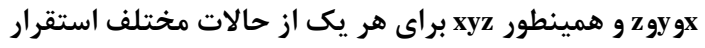

\begin{tabular}{|c|c|c|c|c|c|c|c|c|c|}
\hline$\frac{2}{2}$ & Rmsex & Rmsey & Rmse Z & Rmsexyz & هِارامتر حذفى & $\begin{array}{l}\text { Rmsex } \\
\text { بعد حذف }\end{array}$ & $\begin{array}{l}\text { Rmsey } \\
\text { بعد حذف }\end{array}$ & $\begin{array}{l}\text { RmseZ } \\
\text { بعد حذف }\end{array}$ & $\begin{array}{c}\text { Rmsexyz } \\
\text { بعد حذف }\end{array}$ \\
\hline A & T/FF & T/AT & $I / V F$ & $4 / 119$ & $b_{4}-c_{3}-c_{4}-c_{5}$ & $r / F F$ & $r / \Delta V$ & $1 / V \Delta$ & $r / l r$ \\
\hline $\mathrm{B}$ & $T / T)$ & T/FT & 1/Dr & r/gr & $c_{3}-c_{4}-c_{5}$ & $r / T I$ & T/K & $1 / \Delta r$ & $r|9|$ \\
\hline $\mathrm{C}$ & T/Tr & T/FF & $1 / \Delta r$ & r/gF & $b_{4}-c_{3}-c_{4}-c_{5}$ & T/TT & $r / T Q$ & $1 / \Delta r$ & ( \\
\hline $\mathrm{D}$ & T/Tr & T/GT & $1 / 9 \pi$ & r/AV & $c_{3}-c_{4}-c_{5}$ & T/Tr & T/ब & $1 / 94$ & 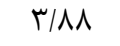 \\
\hline E & 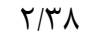 & r/Vq & $1 / \Delta T$ & $r / \vee q$ & $c_{1}-b_{4}-c_{3}-c_{4}-c_{5}$ & T/r & $r / \Lambda \cdot$ & $1 / \Delta r$ & $r / 91$ \\
\hline $\mathrm{F}$ & T/T & $r / F \Delta$ & $1 / \Delta r$ & $r / 9 \Delta$ & $c_{3}-c_{4}-c_{5}$ & $r / 99$ & $T / F V$ & $1 / \Delta F$ & r/qp \\
\hline
\end{tabular}

بهبود دقت اتفاق مىافتد. بنابراين توصيه مىشود كــــ

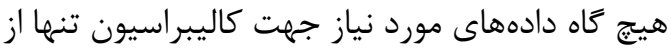

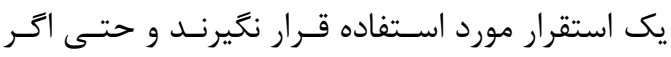

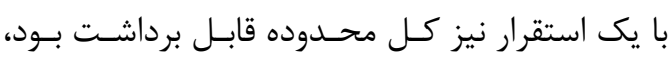

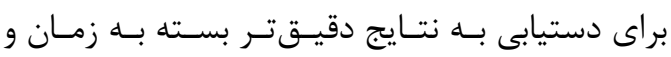

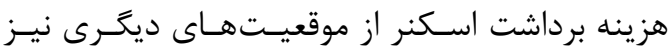

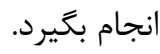
f.ا.در حالـت اسـتقرار در سـه موقعيـت(B) متفــاوت بهترين بهبود دقت اتفاق مىافتد و بعد از آن استـتقرار در يك مكان و تغيير در زاويه قائم دستكاه(سه زاويسه

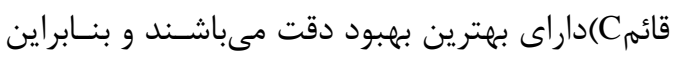

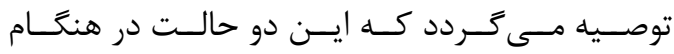

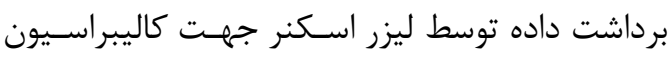
مورد استفاده قرار بخيرند.

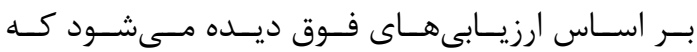

آنجـهـ در تفسـير جــداول فـوق مسى تـوان بيـان نمـود به شرح زير است:

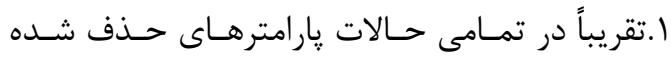

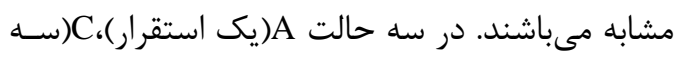

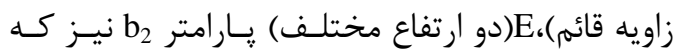

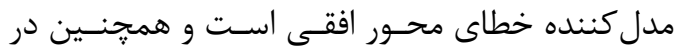

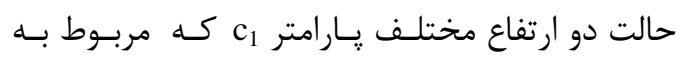

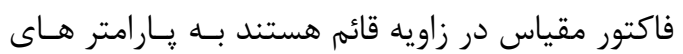

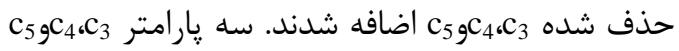

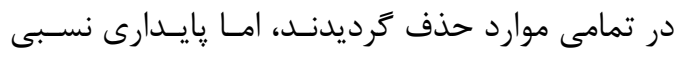
در خصوص ديكر يارامترهاى مدل مذكور وجود دارد.

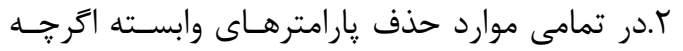

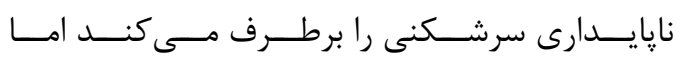
خطاهاى باقيمانده را بسيار كم افزايش مى دهد.

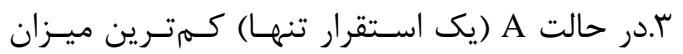




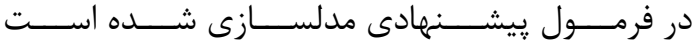

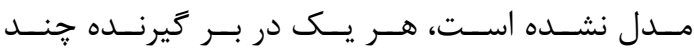

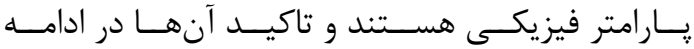
در خصوص يارامترهاى تجربى است كه بعد از مشـاهده

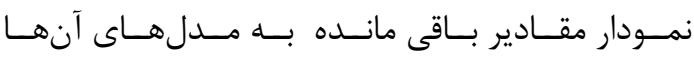

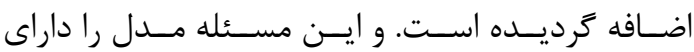

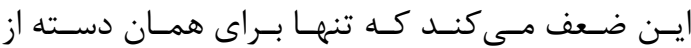

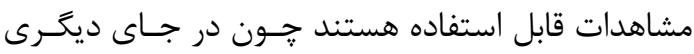

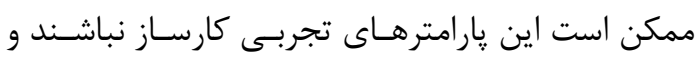

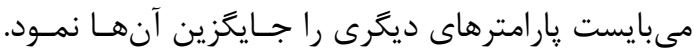
در همـين راسـتا در ادامــه مــدل هــاى مختلفـى كــهـ توسط محققين مختلف در خصوص كاليبراسـيون ليـزر

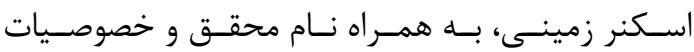

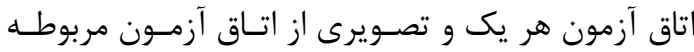
به همراه بهبود دقتى كه محقق بعد از اعمال اين مـدل بر مشاهدات مربوطه بدست آورده است ارائه شده است.

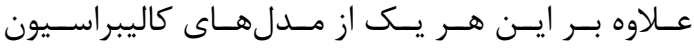
بر مشاهداتى كه توسط ليزر اسكنر موجود در اين يروزه يسه

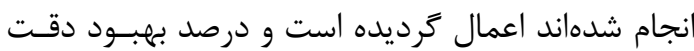
در هر يك مطابق با آنجهه در بخشهاى قبـل بيـان شـد

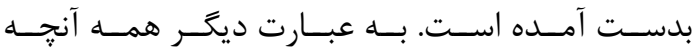

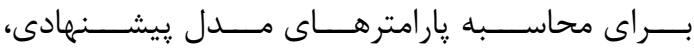
محاسـبه مقــادير اوليـه و ثانويسه دقـت بعـد از اعمــال يارامترهاى مدل در مباحث قبل به تفصيل بيان گرديـد براى هر يك از فرمولهاى محققين نيز صورت يذيرفته مديا

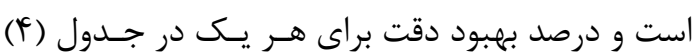

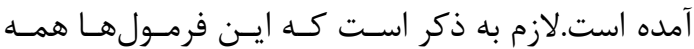

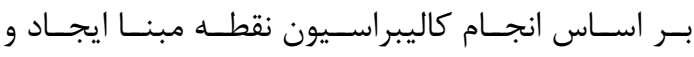
يارامترهاى آنها بدست آمدهاند.

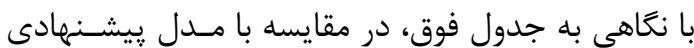
19 يارامترى معادل با روابط || تا سا كه بهبود دقتى

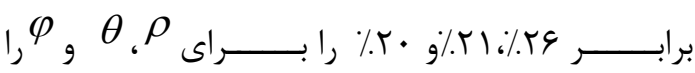
بدست آورد، نتايج زير قابل حصول خواهد بود:

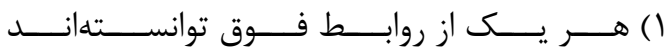
دقت دادههاى ليزر اسكنر مورد تحقيق در اين تـز را
جَگونكَى اسـتقرار ليـزر اسـكنر در برداشـت مشـاهدات

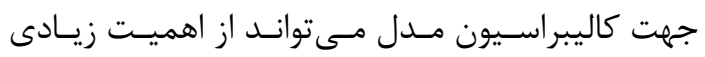

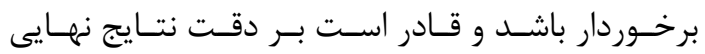

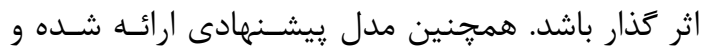

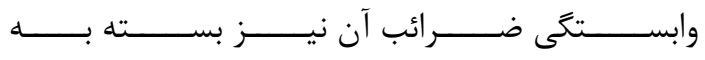

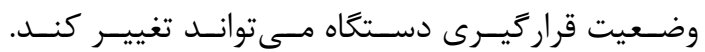
اين مسئله اهميت تعيين استقرارهاى كافى و مناسب رئرئر

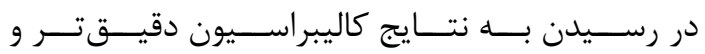
قابل اطمينانتر نشان مى دهد.

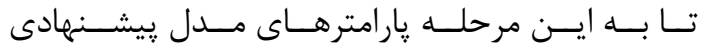

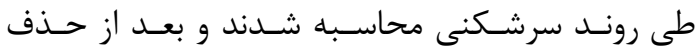
يارامترهاى وابسته مورد ارزيابى قـرار كرفتنـد. و نهايتـاً

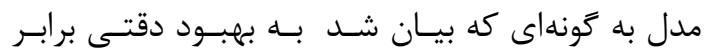

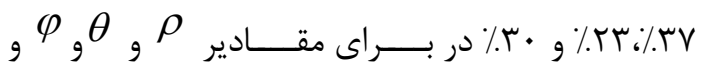

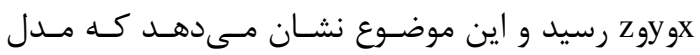
ييشنهادى تا حد مناسبى قـادر اسـت مشـاهدات ليـزر

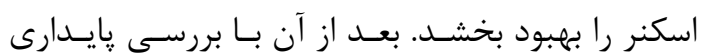
ضرائب مدل مـذكور در تغييـر وضـعيتهــاى گَونـاكون

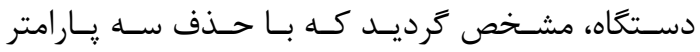

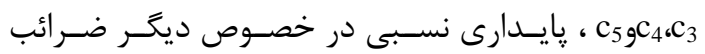
برقرار مىباشد. در ادامه دقت مدل ييشنهادى بـا ديخــر مدل هاى ارائه شده مقايسه و ارزيابى مى گردد.

F-Y-P مقايسه مدل ييشنهادى با مدلهاى موجود در اين مرحله بعد از انجام بررسىهاى مختلف، ارزيـابى ديخرى در خصوص مدل ييشنهادى صورت مىيذيرد و

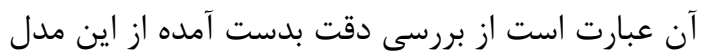

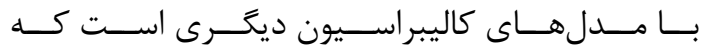
توسط محققين مختلف در خصوص كاليبراسـيون ليـزر

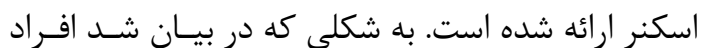

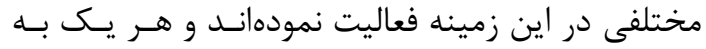

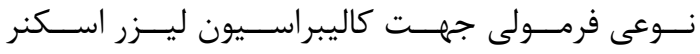
مورد بررسى ارائه كرده اند. امـا آنجــهـ در مــورد فرمـول

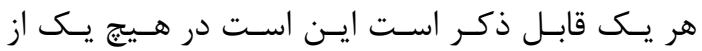
اين فرمولها ساختار داخلى دستخاه به شكل كاملى كه 


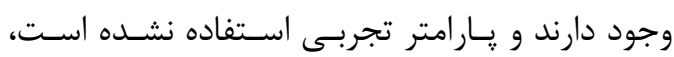

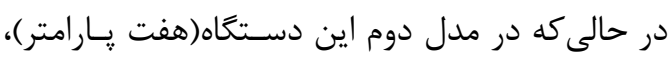

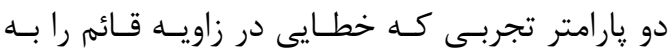

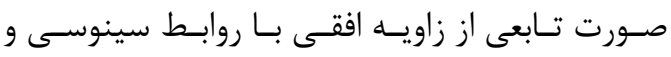

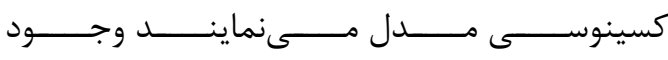
دارد) (c)

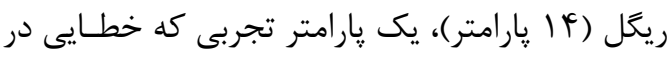

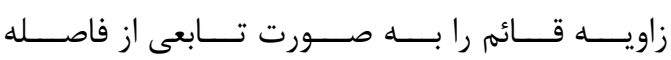
مسدل مسى كنـــ

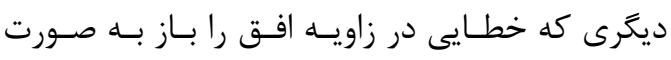
تابعى از فاصله مدل مسىنمايـد وجـود دارد.(

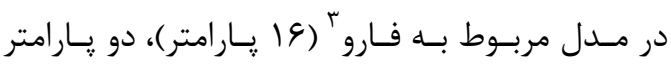

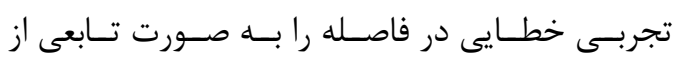

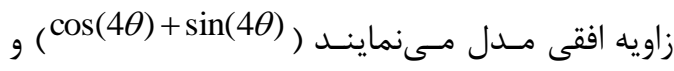

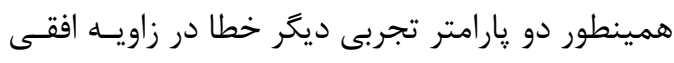

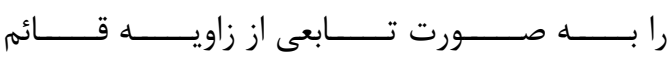

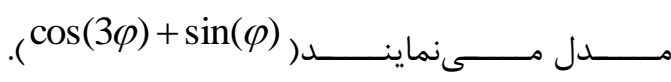

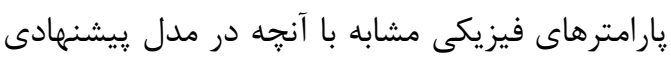

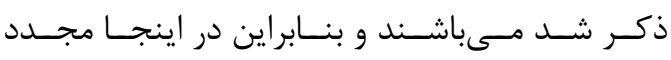
تفسير نمى گر دند.

(V

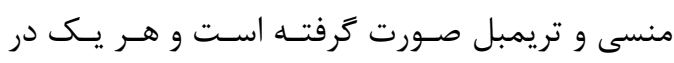

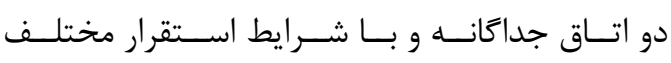

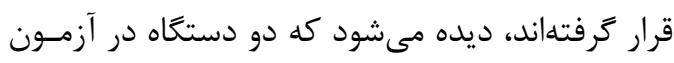

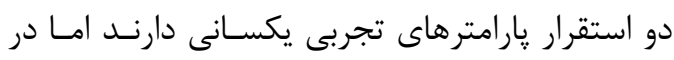

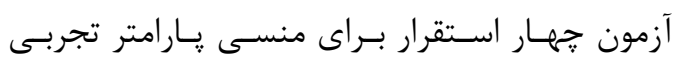

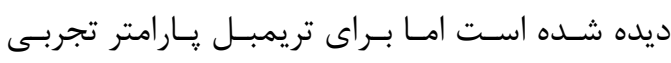

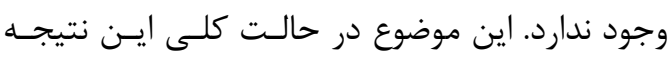

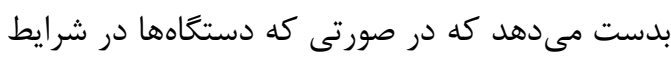

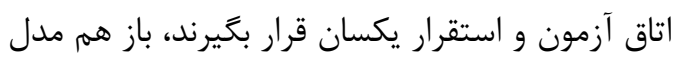
ييشنهادى براى هر يك مىتواند متفاوت مىباشد.

3 Faro
نيز بهبود بخشند.

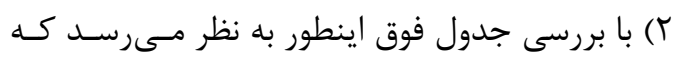

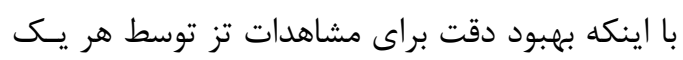

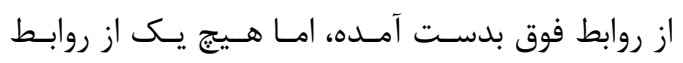

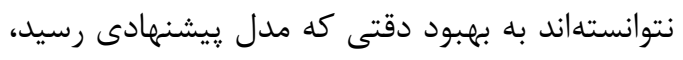

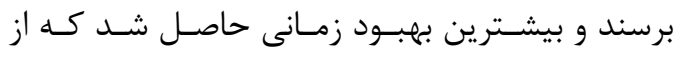
مدل كاليبراسيون بيشنهادى استفاده كرديد.

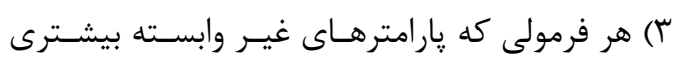

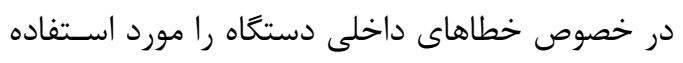

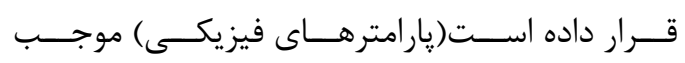
بهبود دقت بيشترى شده است.

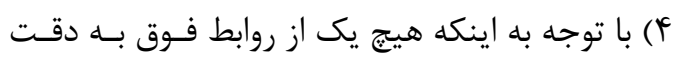

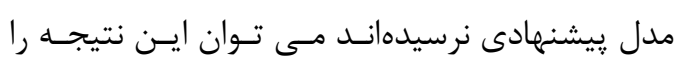

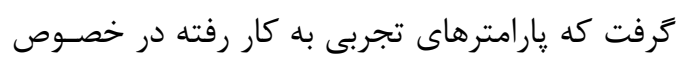

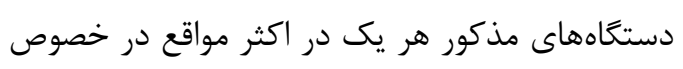

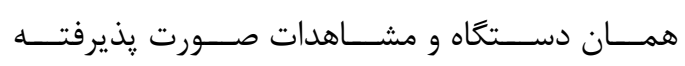

$$
\text { جوابكو مىباشند. }
$$

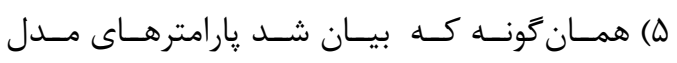

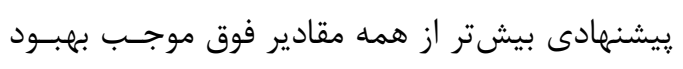

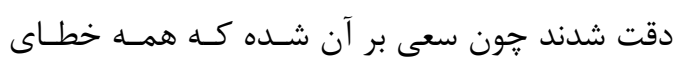

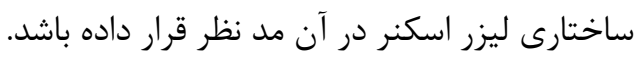

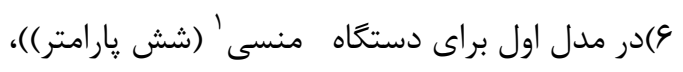

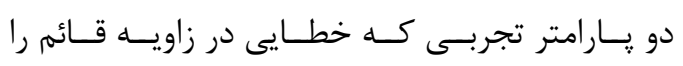

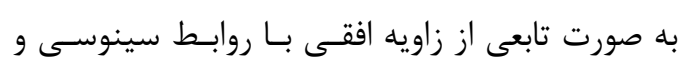

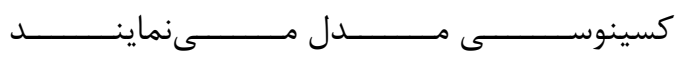

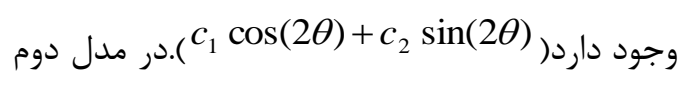

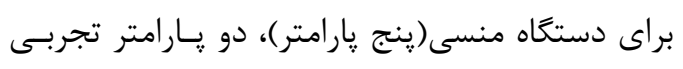

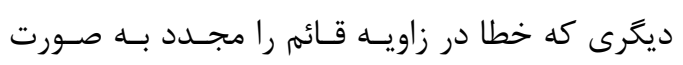

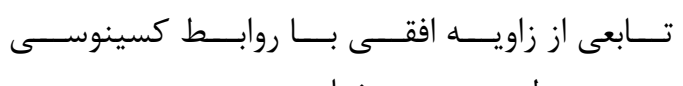

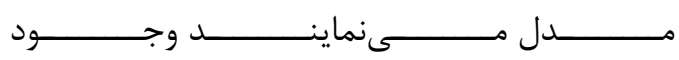
دارد) (20)

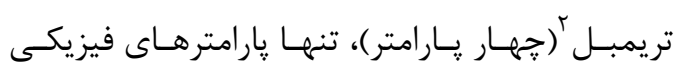

1 Mensi

2 Trimble 
جدول(f):خصوصيات مدل هاى محققين و نتايج حاصل از اعمال آنها بر مشاهدات ليزر اسكنر

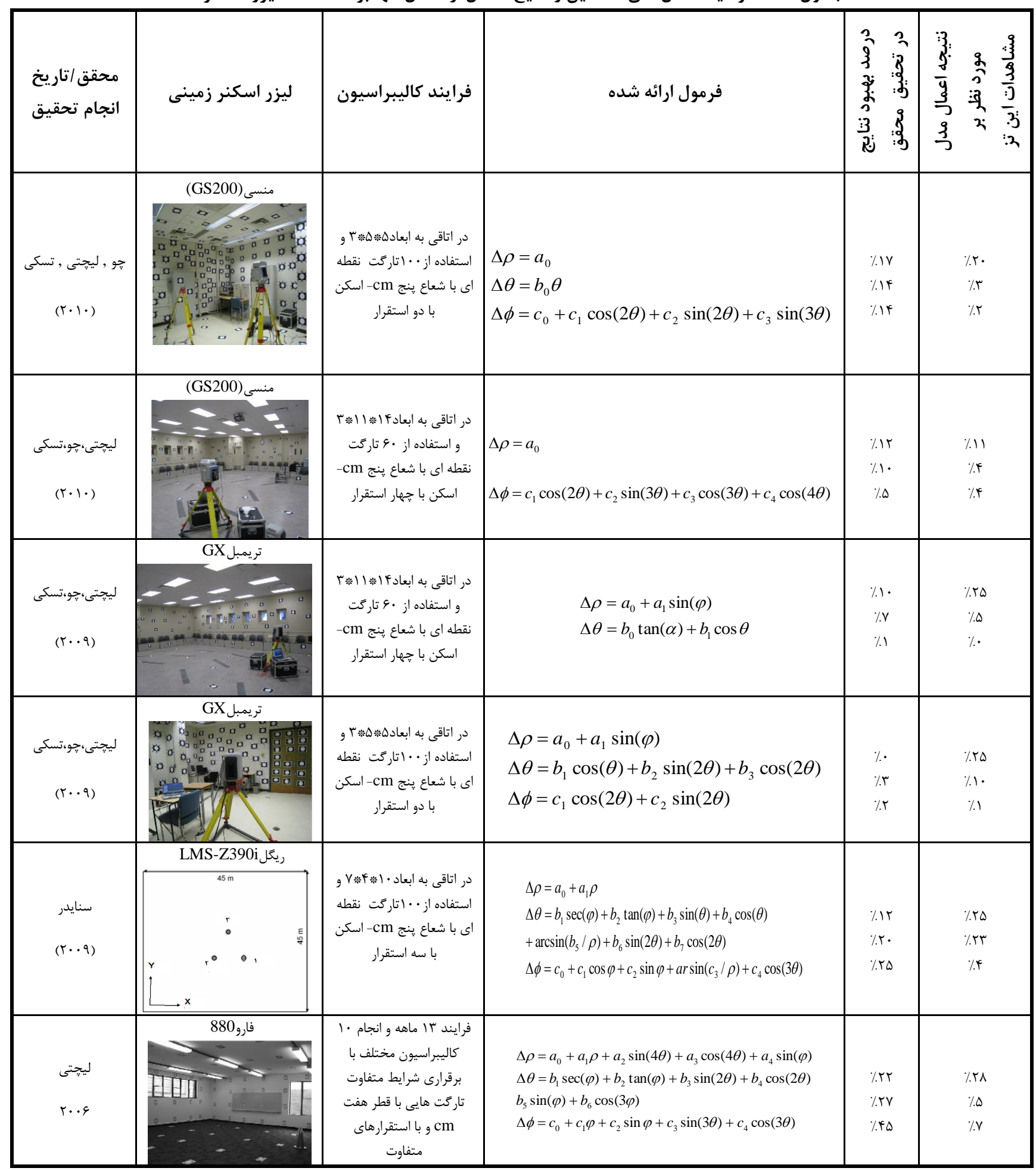

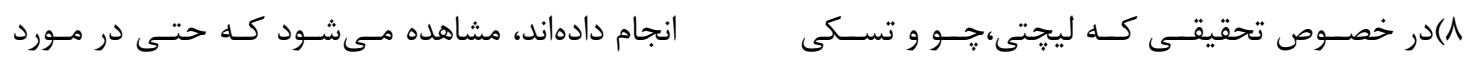


بعد از آن با انجام ترانسفورماسيون دادههاى ليزر اسكنر

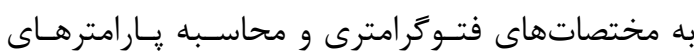
مدل ييشنهادى و بررسى دقت قبل و بعد از اعمال مدل

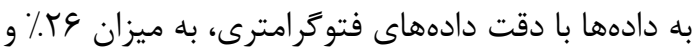

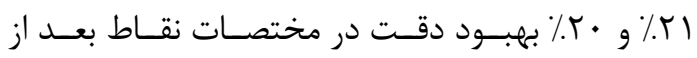
اعمال مدل ديده شد. در مقايسه با مدلهـاى ديخــر از داز

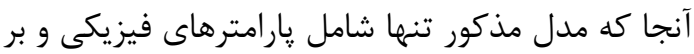

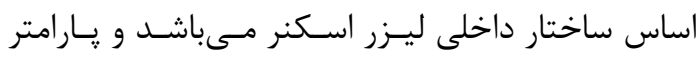

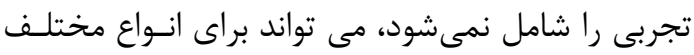
ليزراسكنرها به كار رود.

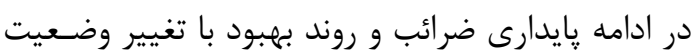

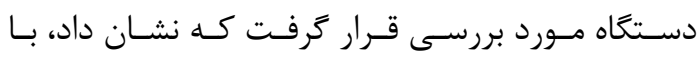

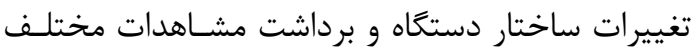

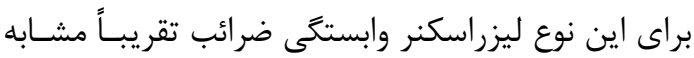

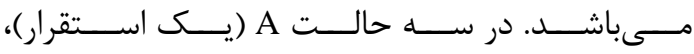

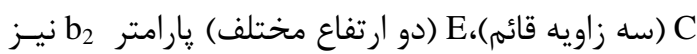
كه مدل كننده خطاى محور افقى اسـت و همجٍنـين در

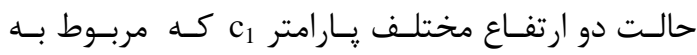

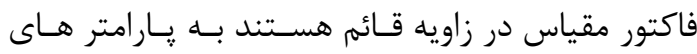

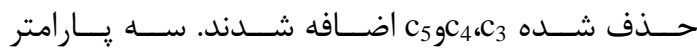
(عدم تعامد محور افقى و لمب قـائم و خـروج از $c_{5} c_{5} c_{4} c_{3} c_{3}$

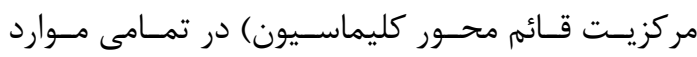
حذف گرديدند، اما پايدارى نسـبى در خصـوص ديخــ يار امترهاى مدل مذكور وجود دارد. علاوه بر مطالب فوق ديده شده كه در يك مدود استقرار تنهـا كمترين ميزان بهبــود دقـت اتفـاق مسى افتــد. بنـابراين توصيه مىشود كه هيج كاه دادهها تنها از يـك اسـتقرار

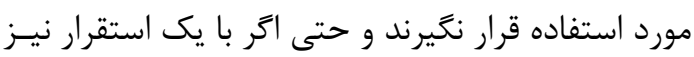

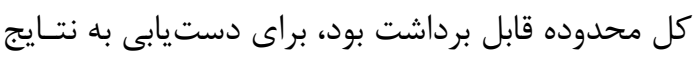

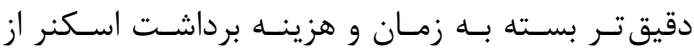
موقعيتهاى ديخرى نيز انجام بخيرد.

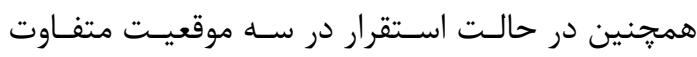
بهترين بهبود دقت اتفاق مىافتـد و بعـد از آن اسـتقرار

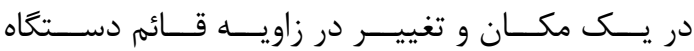

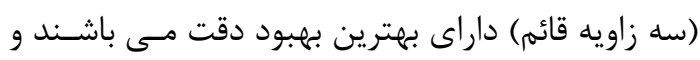

يك دستخاه هم در صورتى كه شـرايط اتـاق آزمـون و

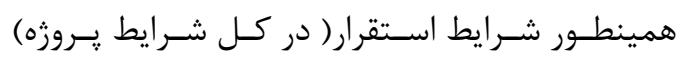
متفاوت باشند باز يارامترهـاى تجربسى بـهـ كـار رفتـهـ

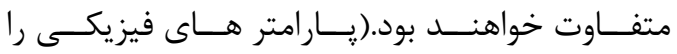
خود محقق به صورت مختلف در نظر گرفته است.) 9)در تحقيق ليجتى، :جو و تسكى ديــده مسىشـود كـهـ

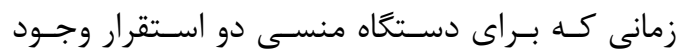
دارد(در آزمون دو استقرار) براى هم مشاهدات اين تز دمان و همم مشاهدات محقق دقت بهبود بيشترى مسى يابـد.

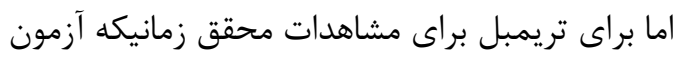
جهار استقرار است بهبود بهتر خواهد بود.

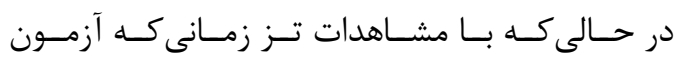

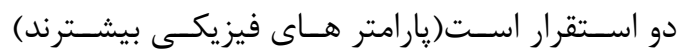

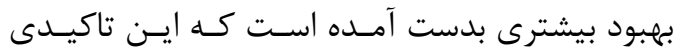

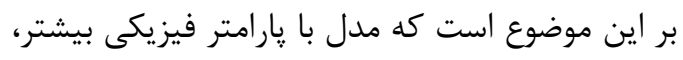

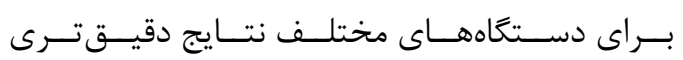

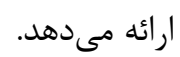

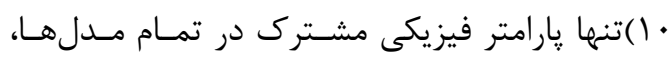

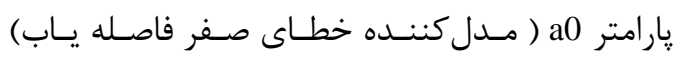

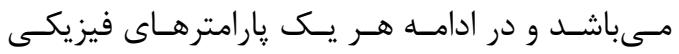
مختلفى استفاده نمودهاند.

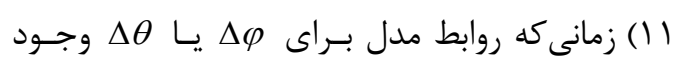
ندارد، از زمانى كه براى هر سه دسته مشاهدات و $\theta$ روابط تصحيح خطا نوشته مى شود، بهبود دقت نهان

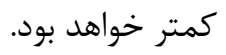

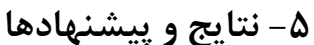

هدف اصـلى در ايـن فصـل كاليبراسـيون ليـزر اسـكنر

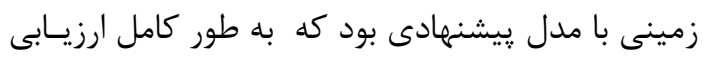

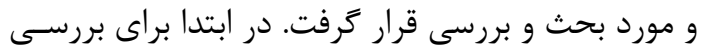

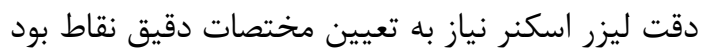

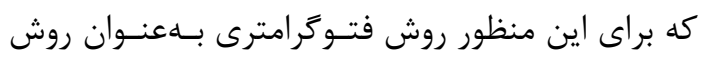

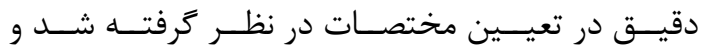

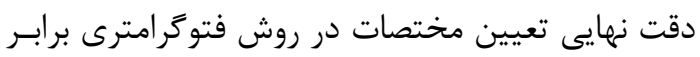

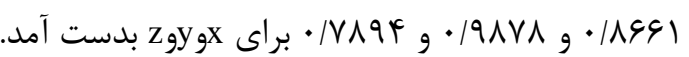




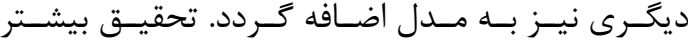

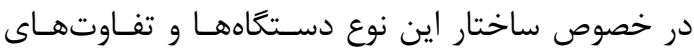

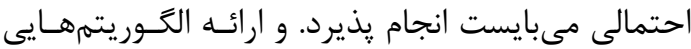

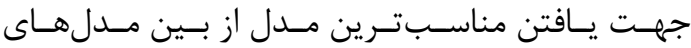

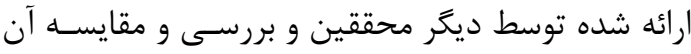
با مدل قيشنهادى، توصيه مى تردد.

[1] Boehler, W., Bbordasvicent, M., Marbs, A., 2003, "Investigating laser scanner accuracy", In Proceeding of FIG Working Week. Paris, France, April $13-17$. URL: http://www.fig.net/pub/fig_2003/index.htm.

[2] Neitzel, F., 2003, " investigation of axes errors of terrestrial laser scanners", Proceeding of the ISPRS Journal of Photogrammetry and Remote Sensing V/5, Vol XXXVI-5/W8, ISSN 1682-1750.

[3] Gielsdorf, F., Rietdorf, A., Gruendig, G., 2004, "A concept for the calibration of laser scanner", In Optical 3-D Measurment Techniques VII, A. Gruen/H. Kahmen(Eds), Vol. II, pp.359-364.

[4] Santala, J., Joala, V., 2003, "on the calibration of a ground-based laser scanner", International Archives of Photogrammetry and Remote Sensing Vol. 32, part 3-2 W5, pp. 193-199.

[5] Soudarissanane, S., Lindenbergh,.R., Gorte,B., 2008, "Reducing the error in terrestrial laser scanning by optimizing the measurement set-up", Journal of the Optical Society of America 4(4), pp. 629-642.

[6] Lichti, D.D., 2008, "A method to test differences between additional parameter sets with a case study in terrestrial laser scanner self-calibaration stability analysis", Photogrammetry and remote sensing, No.63, pp. 169-180.

[7] Hofle, B., Pfeifer, N., 2007, "Correction of laser scanning intensity data:Data and model-driven approaches", Photogrammetry

$$
\begin{aligned}
& \text { بنابراين توصيه مى گردد كـهـ ايسن دو حالـت در هنَــام }
\end{aligned}
$$

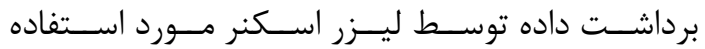

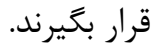

$$
\begin{aligned}
& \text { مدل ارائـه شـده در ايـن تحقيـق جهــت كاليبراسـيون } \\
& \text { ليزراسكنرهايى است كـهـ از نـوع محاسـبه زمـان يــرواز }
\end{aligned}
$$

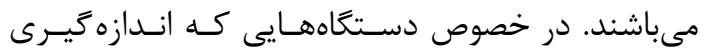

$$
\begin{aligned}
& \text { فاصله را بـهـــرق ديخــر مانـــد مقايسـهـ فــازى و غيـره } \\
& \text { انجام مسىدهنـد، ممكـن اسـت يـارامتر هـاى فيزيكىى }
\end{aligned}
$$

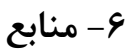

and remote sensing,No. 70, pp. 415-433.

[8] Schulz, T, Ingensand, H., 2004,"Influencing variables,precision and accuracy of tls", INGEO 2004 and FIG Regional Central and Eastern European Conference on Engineering Surveying Bratislava, Slovakia, November 11-13.

[9] Kaasalainen, S., Krooks, A., Kaartinen, A., 2009, "Radiometric calibration of tls with external refrence targets", Proceeding of the Institute of Electrical and Electronics Engineere (IEEE) 72(12), pp. 1671-1684

[10] Lichti, D.D., Licht, M., 2006, "Experiences with terrestrial laser scanner modeling and accuracy assessment, ISPRS Journal of Photogrammetry and Remote Sensing Volume XXXVI, Part 5, pp. 25-27.

[11]Bucksch, A., Lindenbergh,R., Ree, J., 2006, "Error budget of terrestrial laser scanning:influence of the intensity remission on the scan quality", photogrammetry and remote sensing, No.63, pp. 169-180.

[12]Bae, K., Lichti,D.D. , 2007, "On-site selfcalibration using planar features for terrestrial laser scanner", ISPRS Workshop on laser scanning conference, berlin, September 12-16.

[13] Soudarissanane, S., Lindenbergh, R., Ree, J., Bucksch, A., 2005, " Error budget of terrestrial laser scanning:influence of the incidence angle on the scan quality", Jurnal of Photogrammetry and remote sensing,No. 55, pp. 415-433..

[14]Reshetyuk,Y., 2006, "calibration of tls for 
the purposes of geodetic engineering", International Archives of Photogrametry and Remote Sensing, Vol.XXXV, Part B5,

Proceedings of the ISPRS working group V/2, Istanbul, pp. 222-227 


\title{
Representation a complete parametric model to calibrating TLS instruments
}

Elnaz mohammad zanjanipour ${ }^{1 *}$, Masood varshosaz ${ }^{2}$, Mohammad saadat seresht ${ }^{3}$

1. Photogrammetry graduate student, Faculty of Geodesy \& Geomatics Engineering, K.N. Toosi University of Techenology,Tehran,iran

2. Assistant Professor of Surveying Engineering, Faculty of Geodesy \& Geomatics Engineering, K.N. Toosi University of Techcnology,Tehran,iran

3. Assistant Professor of Surveying Engineering, Technical School Campus Two, Tehran University, Tehran,

\begin{abstract}
Surveying has great improvements in data collection techniques in last decade.one of these techniques is laser scanner.with that method we can collect 3D datas automaticly.investigating of the error sources in TLS measurments is rather complicated due to a large number of influencing factors that are quite interrelatred. Thus calibration is an important issue in these devices. several models have been proposed to improve the accuracy of the laser scanners datas until now.each of these models includes some physically parameters and some empirically parameters which have been produced by observation of residuals diagram,in this paper a parametric model based on the internal structure of laser scaner is presented for calibrating these devices. This model compared with another models shows that due to having just physical parameters and not empirical parameters it can be used for a variety of TLS instruments. because of the importance of stability of parameters in a model, stability of them and the correlation between them will be investigated precisely. the results show that this model with a relative stability can improve the accuracy of TLS data.
\end{abstract}

Key words:terrestrial Laser scanner, Calibration,point cloud,parametric model

Correspondence Address: Elnaz mohammad zanjanipour:Tehran,valiasr ave,khaje nasir toosi university,geodesy and geomatic college,analytical photogrammetry lab.Tel:88877073-116

Email: e.zanjanipour@gmail.com 